\title{
LA ARQUITECTURA DE LA HUMILDAD. EL CONVENTO ALCANTARINO DE SAN FRANCISCO DEL ROSAL EN MONDOÑEDO
}

\author{
JAVIER GÓMEZ DARRIBA* \\ Universidade de Santiago de Compostela \\ ORCID iD: https://orcid.org/0000-0001-6712-2983
}

* Miembro IFP (Investigación en Formación y Perfeccionamiento) del Grupo Investigador GI-1510

- Historia del Arte, de la Arquitectura y del Urbanismo, que forma parte del Departamento de Historia del Arte de la Universidade de Santiago de Compostela.

Copyright: C 2020 CSIC. La edición electrónica de esta revista se distribuye bajo los términos de una licencia de uso y distribución Creative Commons Reconocimiento 4.0 Internacional (CC BY 4.0).

Cómo citar/Citation: Javier Gómez DARRIBA, "La arquitectura de la humildad. El convento alcantarino de San Francisco del Rosal en Mondoñedo", Cuadernos de Estudios Gallegos, 67, núm. 133 (2020), págs. 103-132, https://doi.org/10.3989/ceg.2020.133.04 


\title{
LA ARQUITECTURA DE LA HUMILDAD. EL CONVENTO ALCANTARINO DE SAN FRANCISCO DEL ROSAL EN MONDOÑEDO
}

\section{RESUMEN}

En 1727 el obispo fray Juan Muñoz y Salcedo decidió establecer en la ciudad de Mondoñedo el primer y único convento de la Reforma de San Pedro de Alcántara en Galicia. Desde entonces y hasta 1731 se construyó bajo la dirección del lego y maestro de obras fray Lorenzo de Santa Teresa. Actualmente solo se conserva la iglesia, la capilla de la Venerable Orden Tercera y uno de sus claustros. Nuestro objetivo en el presente trabajo es explicar los motivos por los que se erigió, dar a conocer a los maestros y canteros que lo edificaron, las distintas fases de la construcción, describir su morfología original, y reseñar asimismo sus primitivos altares. Para ello nos valdremos de varios fondos documentales y de antiguas fotografías.

Palabras ClaVE: Arquitectura, urbanismo, siglo XVIII, Orden de San Francisco, patrocinio episcopal, Mondoñedo.

\section{A ARQUITECTURA DA HUMILDADE. O CONVENTO ALCANTARINO DE SAN FRANCISCO DO ROSAL EN MONDOÑEDO}

\section{RESUMO}

En 1727 o bispo frei Juan Muñoz y Salcedo decidiu establecer na cidade de Mondoñedo o primeiro e único convento da Reforma de San Pedro de Alcántara en Galicia. Dende entón e ata 1731 construíuse baixo a dirección do freire e mestre de obras frei Lorenzo de Santa Teresa. Actualmente só se conserva a igrexa, a capela da Venerable Orde Terceira e un dos seus claustros. O noso obxectivo no presente traballo é explicar os motivos polos que se erixiu, dar a coñecer os mestres e canteiros que o edificaron, as distintas fases da construción, describir a súa morfoloxía orixinal, e reseñar tamén os seus primitivos altares. Pra isto servirémonos de varios fondos documentais e de antigas fotografías.

Palabras Clave: Arquitectura, urbanismo, século XVIII, Orde de San Francisco, patrocinio episcopal, Mondoñedo.

\section{THE ARCHITECTURE OF HUMILITY. THE ALCANTARINE CONVENT OF SAN FRANCISCO DEL ROSAL IN MONDOÑEDO}

\begin{abstract}
In 1727 the bishop Fray Juan Muñoz y Salcedo decided to establish in the city of Mondoñedo the first and only convent of the San Pedro de Alcántara Reform in Galicia. From then and until 1731 it was built under the direction of the friar and master builder Fray Lorenzo de Santa Teresa. Currently only the church, the chapel of the Third Order and one of its cloisters are preserved. Our objective in the present work is to explain the reasons for which it was erected, publicize the masters builders and stonecutters who built it, the different phases of the construction, describe its original morphology and also indicate its primitive altars. For this we will use several documentary funds and old photographs.

KEY WORDS: Architecture, urbanism, $18^{\text {th }}$ century, Saint Francis Order, Episcopal patronage, Mondoñedo.
\end{abstract}


Recibido/Received: 19/09/2019

Aceptado/Accepted: 07/02/2020

$\mathrm{E}$

n 1705 fray Juan Muñoz y Salcedo fue designado obispo de Mondoñedo. Este monje jerónimo de raíces giennenses, antiguo confesor de Carlos II y prior del monasterio de San Lorenzo del Escorial, rigió la diócesis hasta su muerte en 1728. Su mandato se caracterizó por el patrocinio de múltiples reformas urbanas y arquitectónicas en la capital episcopal, siendo la más llamativa la de la fachada de la catedral. En ellas puso un incesante y denodado empeño nunca antes visto en un prelado mindoniense. La empresa de mayor complejidad de todo su episcopado fue la de financiar nuevos conventos para las distintas ramas de la Orden franciscana, pues ello no solo implicó destinar grandes partidas económicas con que sufragar las fábricas arquitectónicas y el mobiliario litúrgico de dichas casas monásticas, sino también invertir considerables sumas de dinero y muchos quebraderos de cabeza en resolver los pleitos en los que se vio envuelto por su causa ${ }^{1}$.

Fray Juan Muñoz salvó de una muerte segura a las monjas concepcionistas del convento de la Encarnación, pues su casa, levantada en la pendiente de una colina en el decenio de 1650, se había convertido en una ruina al poco tiempo de terminarse $\mathrm{e}^{2}$. El prelado tuvo que litigar durante años con los patronos del cenobio $\mathrm{y}$ con el Cabildo para que las religiosas abandonasen el convento extramuros y se instalasen en uno ex novo en el núcleo urbano. E igualmente para que estas pudiesen vivir en el Palacio Episcopal mientras se edificaba su nueva morada ${ }^{3}$.

\footnotetext{
1 Sobre la figura de este obispo debe consultarse como trabajo de referencia a Enrique CAL PARDo, "Episcopologio Mindoniense. Primera mitad del siglo XVIII", Estudios Mindonienses, núm. 17 (2001), págs. 277-336. Esta publicación fue integrada dos años después en una monografía que por su carácter compilatorio y por no variar un ápice lo dicho será la que citemos a partir de ahora. Enrique CAL PARDo, Episcopologio Mindoniense, Santiago de Compostela, CSIC-Xunta de Galicia, Instituto de Estudios Gallegos "Padre Sarmiento"; Mondoñedo-Ferrol, Estudios Mindonienses, 2003 (Anejos de Cuadernos de Estudios Gallegos, 28), págs. 657-710. Para una visión general del patrocinio urbanístico de este prelado y de sus sucesores en la silla v. Alfredo Vigo Trasancos, "La ciudad de Mondoñedo en el siglo XVIII. La renovación urbana de una antigua sede episcopal", Estudios Mindonienses, núm. 15 (1999), págs. 519-553.

2 Javier Gómez DarRIBA, “«Reconstruyendo» una ruina del siglo XVII. El desaparecido convento de la Encarnación de Mondoñedo", Sémata, núm. 31 (2019), págs. 251-272.

3 Eduardo Lence-Santar y Guitián, Mondoñedo: El Convento de la Concepción, Mondoñedo, César G. Seco, 1910; Santos San Cristóbal Sebastián, Monasterio de la Concepción de Mondoñedo, Lugo, Diputación Provincial de Lugo, 2001.
} 
Aparte de costear en buena medida esta fábrica, hizo lo propio con la iglesia de los frailes terciarios de San Martiño de Vilalourente o de Os Picos, establecidos en las afueras de la ciudad desde finales del siglo XIV ${ }^{4}$. Por último, en 1727 fructificó su iniciativa de instaurar un convento alcantarino en la capital, después de que se hubiesen frustrado decenas de fundaciones monásticas hasta fechas muy recientes ${ }^{5}$.

El propósito de este trabajo es reconstruir el espacio urbano y la morfología original de aquel convento. Máxime cuando nunca ha despertado especial interés en la historiografía pese a ser el único de la Reforma de San Pedro de Alcántara en Galicia ${ }^{6}$. Ello quizá se deba a que plantear su reconstrucción no resulte sencillo dada la ausencia de fuentes gráficas coetáneas a su erección, inconveniente al que se suman las diversas modificaciones que sufrió en el siglo XIX tras la exclaustración ${ }^{7}$. Y sobre todo, el paulatino abandono que experimentó durante la segunda mitad del XX, que culminó con la pérdida de la mitad de los edificios que lo integraban. Todavía en fechas tan recientes como la década de 1980 se demolieron las antiguas estancias comunitarias a excepción de un claustrillo ${ }^{8}$. Además de este, también se salvaron la iglesia conventual y la capilla de la Venerable Orden Tercera ${ }^{9}$. El templo y su entorno fueron rehabilitados entre 2008 y 2010 siguiendo un proyecto de Manuel Gallego Jorreto ${ }^{10}$. Mientras que la capilla de la V.O.T. continúa cumpliendo sus fines litúrgicos (fig. 1). Pese a todas estas alteraciones hemos podido reconstruir la historia y la primigenia morfología del conjunto monástico. Para ello nos hemos valido de multitud de manuscritos custodiados en distintos archivos, así como de fotografías de finales del siglo XIX y principios del XX que forman parte de colecciones privadas (figs. 2-4).

\footnotetext{
4 María del Mar Graña Cid, Las órdenes mendicantes en el obispado de Mondoñedo. El convento de San Martín de Villaoriente (1374-1500), Salamanca, Estudios Mindonienses, 1990.

5 Todo parece indicar que ya en 1601 el obispo Diego González Samaniego había intentado traer a esta ciudad a los descalzos, CAL PARDo, Episcopologio..., pág. 415.

6 Todavía hoy la bibliografía de referencia sobre este monasterio la constituyen dos centenarias monografías de Eduardo Lence-Santar y Guitián, Mondoñedo: La Orden Tercera, Mondoñedo, César G. Seco Romero, 1910; y Mondoñedo: El Convento de Alcántara, Mondoñedo, César G. Seco Romero, 1910.

7 Desde 1835 en adelante acogió temporalmente al Seminario de Santa Catalina; fue salón teatro; sirvió de alojamiento para tropas militares; también fue cuartel de la Guardia Civil; contuvo diferentes escuelas; una estación de telégrafos; se establecieron allí juzgados y audiencias; y en la iglesia llegaron a asentarse temporalmente los padres de la Congregación de la Pasión, Lence-SANTAR, Mondoñedo: El Convento de Alcántara, págs. 23-31.

8 Fruto de esta actuación surgió un amplio solar destinado hoy a aparcamiento municipal.

9 José Isidro Fernández Villalba, Santos San Cristóbal Sebastián, El convento de San Pedro de Alcántara, Mondoñedo, Mancebo, 2006, págs. 23, 60-96.

10 Este data de 2003, Manuel Gallego Jorreto, “Actuaciones en Mondoñedo. Lugo. España”, Tribuna de la Construcción, núm. 118 (2015), págs. 132-137. El templo se halla secularizado y hoy es sede del Centro Cultural da Alcántara. Centro de Interpretación do Camiño Norte.
} 


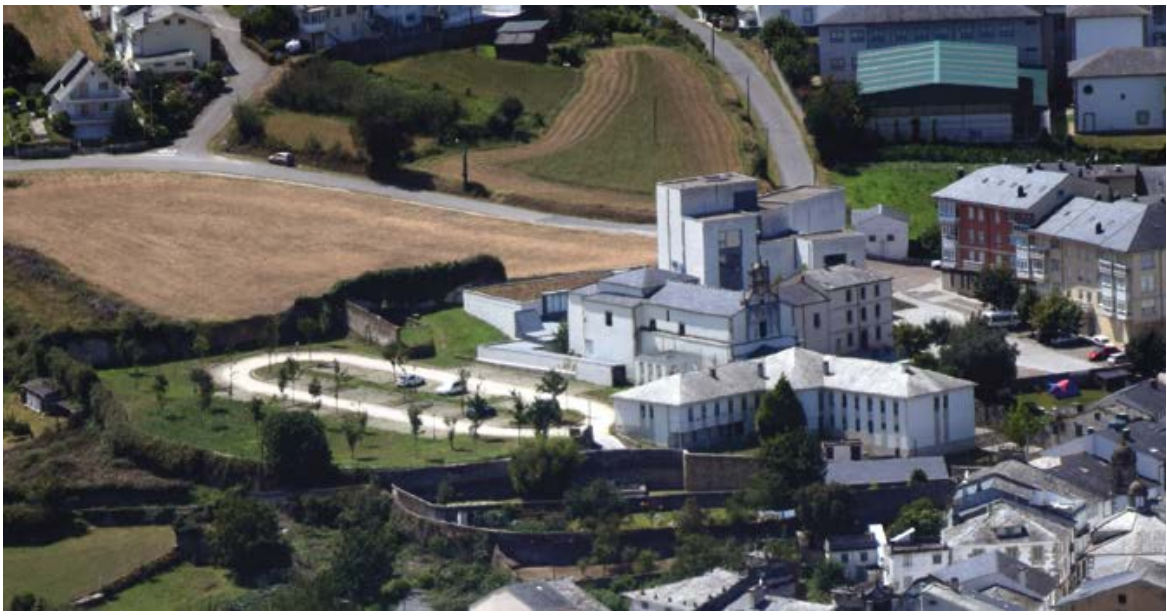

Fig. 1. Vista del entorno del antiguo convento de San Francisco del Rosal desde la cima del Monte Padornelo. (Fotografía del autor).

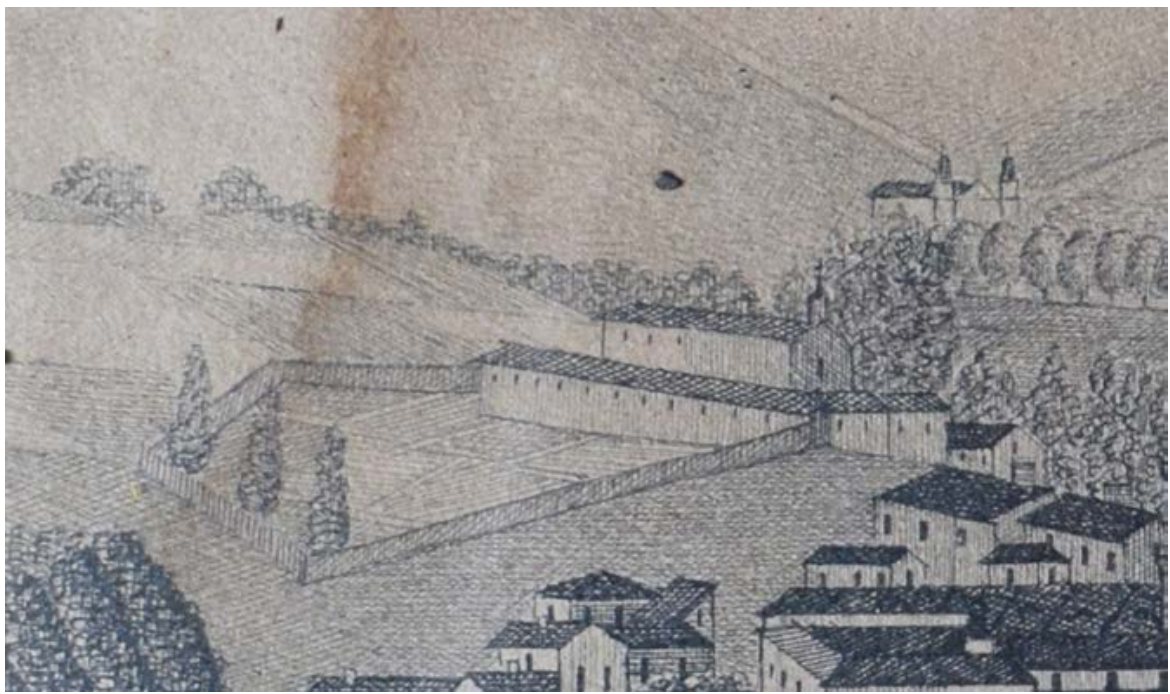

Fig. 2. Dibujo a pluma de José Portal y Baquedano (1844) donde se aprecia el convento alcantarino. Biblioteca Capitular de la Catedral de Mondoñedo. (Fotografía del autor). 


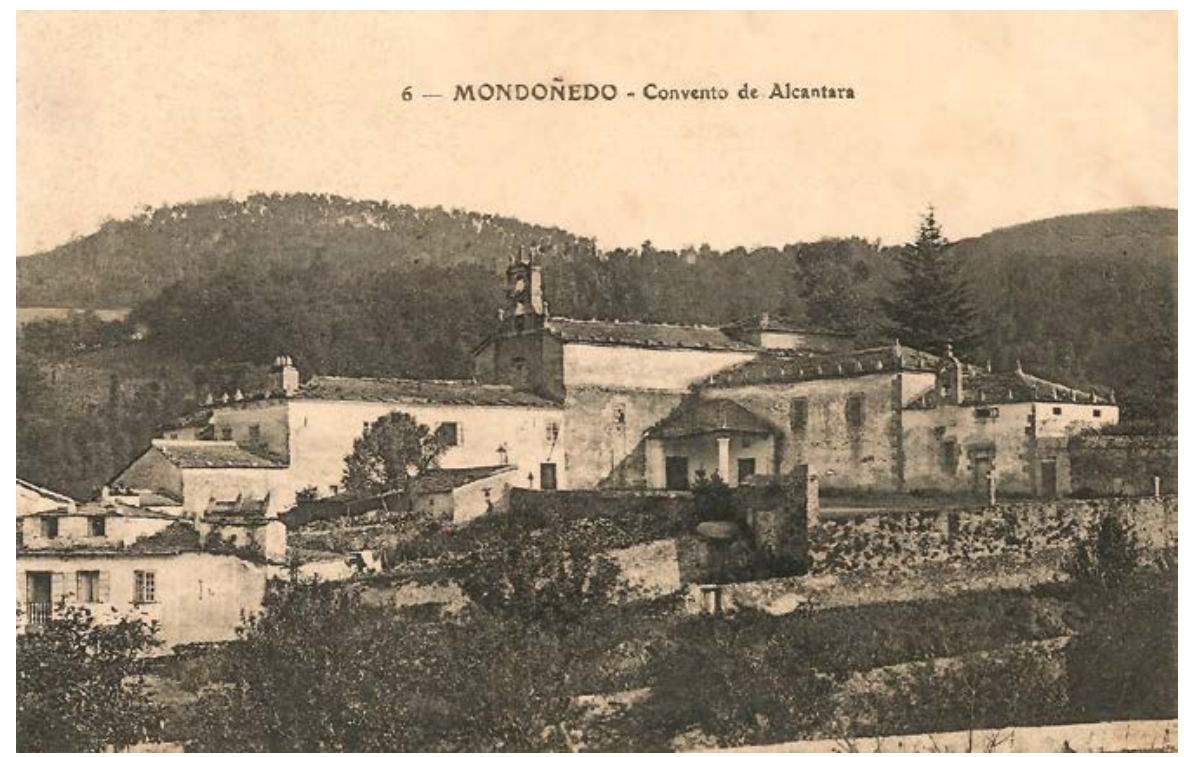

Fig. 3. Postal de finales del siglo XIX o en todo caso anterior a 1911. En ella se distingue el compás conventual, la iglesia y la capilla de la V.O.T. con su sacristía. (Colección F. Marful).

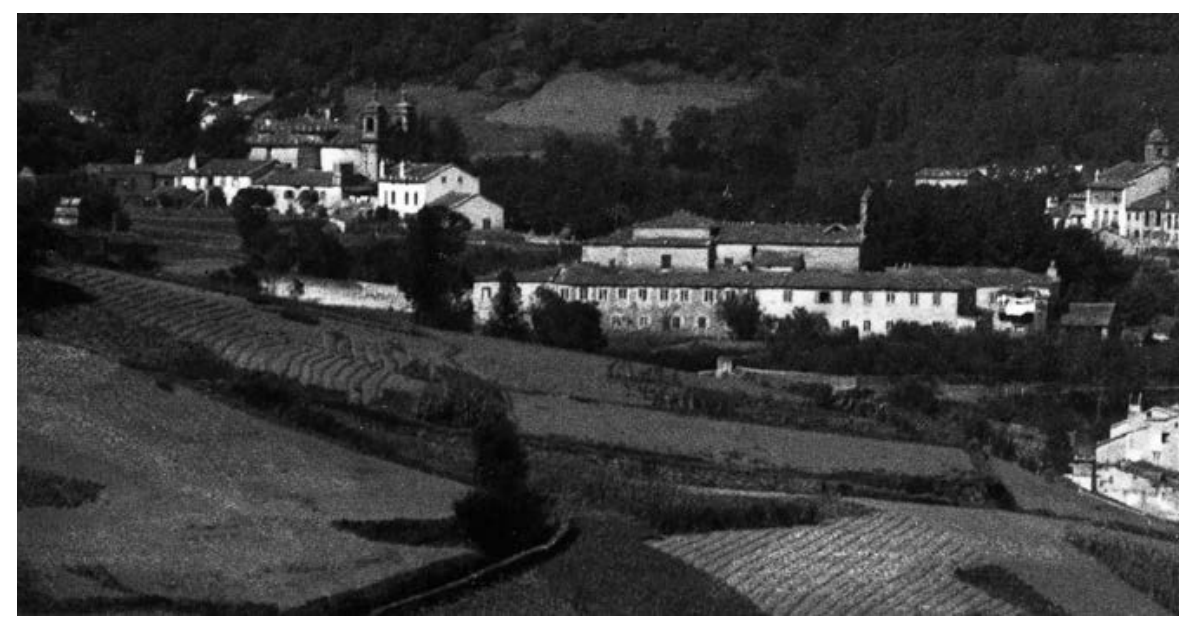

Fig. 4. Antiguas dependencias comunitarias del convento de San Francisco del Rosal en una fotografía de ca.1906. (Colección Roberto Reigosa Méndez). 


\section{FUNDACIÓN Y CONSTRUCCIÓN DEL CONVENTO}

\subsection{El obispo Muñoz y la devoción a san Pedro de Alcántara}

Muñoz y Salcedo logró en sus tres últimos años de episcopado en Mondoñedo (1726-1728) lo que durante décadas había sido una utopía: convencer al Cabildo, a las órdenes religiosas, al párroco de Santiago y al Ayuntamiento, de la conveniencia de fundar un nuevo convento en la ciudad. El obispo tenía especial interés en que allí se instalasen los frailes de San Pedro de Alcántara, pues a su juicio esta rama franciscana era la más ejemplarizante en cuanto al estricto cumplimiento de la observancia religiosa, y su espíritu casaba a la perfección con el de los vecinos mindonienses, tan necesitados por otra parte de clérigos que les predicasen y confesasen. En su empeño por instaurar el convento hizo todo tipo de donaciones, y según Lence-Santar tuvo la intención de mudarse a él una vez terminado, cosa que no se produjo porque falleció en 1728 sin verlo concluido ${ }^{11}$.

Tres años antes de que el prelado confirmase su intención de traer a los alcantarinos a la capital, él y su sobrino, el canónigo maestrescuela Pedro de Leiva, habían dado evidentes muestras de la devoción que les despertaba san Pedro de Alcántara. En el santuario de Los Remedios, de patronato episcopal y cuya mayordomía ocupaba el propio Leiva, decidieron erigir un retablo en honor del santo cacereño. Y en octubre de 1724 comparecieron ante notario para formalizar la escritura de su ejecución con los escultores y vecinos mindonienses Bernabé García de Seares, Bernabé Varela, Lázaro Fajardo y Francisco Rosendo Ibáñez Pacheco $^{12}$. En junio de 1725 el mueble estaba terminado y Leiva contrató con el pintor Dionisio do Monte Neira y Solloso su policromía y dorado ${ }^{13}$. El fervor de

\footnotetext{
${ }^{11}$ Lence-SAntar, Mondoñedo: El Convento de Alcántara, pág. 50. La vida monástica no le era ajena al obispo. Fue prior en los monasterios jerónimos de Santa Catalina de Talavera y de San Lorenzo del Escorial. Además, entre 1710-1714 se hospedó en el convento de San Francisco de Viveiro para evitar convivir con las monjas concepcionistas en el Palacio Episcopal mientras no construían su nuevo convento, CAL PARdo, Episcopologio..., págs. 686-689.

${ }^{12}$ Dicha escritura se rubricó el 9 de octubre. Leiva contaba con la aprobación del obispo para situarlo en el lado de la Epístola, y podría elegir las imágenes que figurarían en él. La traza del mueble se debió a Bernabé García de Seares, a quien también se le adjudicó la obra por 2500 reales, ArCHIVo HistóRICO Provincial de Lugo (a partir de ahora AHPLu), Protocolos Notariales, Mondoñedo (a partir de ahora PNM), Juan Antonio de Villar y Rubiños, leg. 8229-2, fols. 310r. ${ }^{\circ}-311 v{ }^{\circ}$. El parentesco entre Leiva y el obispo fue advertido por Lence-SAnTAR, Mondoñedo: El Convento de Alcántara, págs. 33, 50, 52; del mismo autor v. Mondoñedo. El Convento de San Martín de Villaoriente o de los Picos, Lugo, Sucr. de A. Villamarín, 1912, págs. 89, 92.

${ }^{13}$ Esta escritura pasó ante notario el 9 de dicho mes. Leiva había dispuesto cédulas por Mondoñedo, Lourenzá y Ribadeo, a fin de que concurriesen artistas que quisieran tomar la obra. El día previo a la firma del contrato se le adjudicó a Dionisio por 2230 reales. Este trabajaría con la ayuda de su fiador el escultor José de Neira. Tendrían que terminarlo para finales de septiembre de aquel año, AHPLu, PNM, Juan Antonio de Villar y Rubiños, leg. 8230-1, fols. 183r. ${ }^{\circ}-184$ r. $^{\circ}$; Eduardo Lence-SANTAR y Guití́n, Mondoñedo: El Santuario de los Remedios, Mondoñedo, César G. Seco Romero, 1909, pág. 12. Este retablo se
} 
este canónigo y mano derecha del obispo hacia san Pedro de Alcántara no solo se manifestó en estos contratos. También se constató en las generosas donaciones que otorgó al convento, o en el hecho de que fuese el primer síndico y superintendente de sus obras. Además, confesó su veneración al santo en su testamento de $1729^{14}$.

\subsection{Fundación y llegada de los primeros frailes descalzos}

En noviembre de 1726 Muñoz envió sendas cartas al Ayuntamiento de Mondoñedo y al Cabildo rogándoles que consintiesen la fundación de un convento alcantarino en la ciudad. En estas epístolas elogió las virtudes de los frailes, la idoneidad de su presencia en la capital del obispado, e incluso hizo un símil entre la instalación de los mismos y la construcción de fuentes que emprendía en la urbe. Creía que si con estas lograba aliviar la sed física de los mindonienses, con la llegada de los descalzos aliviaría su sed espiritual ${ }^{15}$. En aquel mes también se carteó con el provincial de San Pablo para convencerle de lo mismo, y aprovechó para alabar las virtudes de una localidad como Mondoñedo, habitada por genios apacibles que distaban mucho del concepto de lo que son los gallegos ${ }^{16}$. La propuesta del prelado fue cuajando de forma paulatina. En diciembre la validó dicha provincia de San Pablo, rectora de la futura comunidad alcantarina ${ }^{17}$. En enero de 1727 hizo lo propio el párroco de Mondoñedo ${ }^{18}$. Y en agosto obtuvo la apro-

conserva en la actualidad en el brazo del crucero del lado del Evangelio. Sobre el mismo v. Francisco Javier Novo SÁNCHEz, "Retablos barrocos de la ciudad de Mondoñedo", en Francisco Singul Lorenzo (dir.), Rudesindus. La tierra y el templo. Catedral de Mondoñedo. 8 de mayo - 29 de junio, 2007, Santiago de Compostela, Xunta de Galicia, págs. 285, 292.

${ }_{14}$ Pasó ante notario el 6 de marzo, AHPLu, PNM, Lorenzo Prieto y Solloso, leg. 6261-9, fols. 121r. $122 v^{\circ}{ }^{\circ}-123 r^{\circ}, 125 v^{\circ}$.

15 Archivo de la Catedral de Mondoñedo (a partir de ahora ACMon), Actas Capitulares, vol. 17, fols. 35r. ${ }^{\circ}-36 r .^{\circ}$; Arquivo Municipal de Mondoñedo (a partir de ahora AMMon), Carp. 944, Libro de Actas (1726-1730), 1726, s/f; Lence-SAnTAR, Mondoñedo: La Orden Tercera, pág. 1; del mismo autor Mondoñedo: El Convento de Alcántara, págs. 11-13; y Mondoñedo. El Convento de San Martín..., págs. 19-20; CAL PARDo, Episcopologio..., págs. 693-694. La carta que el obispo envió al Ayuntamiento fue transcrita por Lence-Santar y recopilada por José Isidro FernáNDEZ VillaLbA, Mondoñedo, regreso al pasado VII. Recopilación de artículos publicados en diversos medios de comunicación por Don Eduardo Lence-Santar y Guitián, Mondoñedo, Suc. de Mancebo, 2010, págs. 13-14.

16 Atanasio López, "Convento de San Pedro de Alcántara de Mondoñedo. (Fragmentos de una Chrónica ms.)”, Archivo Ibero-Americano, núm. 28 (1918), págs. 75-76.

17 Lence-Santar, Mondoñedo: El Convento de Alcántara, pág. 13; y Mondoñedo. El Convento de San Martín..., pág. 88 .

${ }^{18}$ Este expresó que no se opondría al establecimiento de los frailes porque los desvelos espirituales del obispo estaban más que justificados, AHPLu, PNM, Juan Antonio de Villar y Rubiños, leg. 8230-3, fols. 2r. ${ }^{\circ}-2$ v. ${ }^{\circ}$, y leg. 7383-2, 1727, fols. 2r. ${ }^{\circ}-3$ r. ${ }^{\text {; }}$, Lence-SAnTAR, Mondoñedo: La Orden Tercera, pág. 1. En febrero de 1727 el Ayuntamiento de Lugo aprobó escribir al rey para que validase la pretendida fundación después de que el Consistorio mindoniense le hubiese comunicado este asunto, AHPLu, Concello de Lugo, Actas Capitulares (1726-1727), leg. 30, fol. 50r. ${ }^{\circ}$. 
bación real y la de los franciscanos de Vilalourente, después de que estos hubieran concordado con el provincial firmar unas capitulaciones que habría de ratificar el papa ${ }^{19}$.

Todo estaba dispuesto para poner en marcha el convento y el 12 de septiembre se escrituró su fundación. Aquel día Muñoz recalcó ante notario que el curato de Santiago de Mondoñedo superaba las 6.000 almas. Su circunscripción no solo acogía a los habitantes de la ciudad, sino también a los de buena parte de los alrededores. El obispo creía que esta cifra era absolutamente desproporcionada para que la atención espiritual de los vecinos recayese en la figura de un único párroco, y consideraba que los frailes de Os Picos no podían complementar la labor pastoral de dicho cura, pues al estar su convento a media legua del núcleo urbano y en medio de un zerro de tan âspero y rrepechoso camino, el acceso al mismo resultaba verdaderamente dificultoso para la mayoría de la población. Dijo también que la ciudad estaba necesitada de fundaciones monásticas desde tiempo inmemorial, y que estas nunca prosperaban por culpa del Cabildo, que siempre las combatía con la excusa de que los entierros y dotaciones que se produjesen en un nuevo convento perjudicarían notablemente a su ya paupérrima fábrica ${ }^{20}$.

En esta ocasión nada hacía prever que la fundación de Muñoz se malograría, pues contaba con todas las licencias pertinentes, inclusive la del Real Consejo. Además había contribuido a la consecución de algunos terrenos en los que erigir el cenobio y donado 12.000 ducados para su edificación. De hecho, desde la semana anterior a esta escritura, concretamente desde el 6 de septiembre de 1727, se hallaban en Mondoñedo tres alcantarinos enviados por el provincial de la Orden con la finalidad de admitir la fundación y de reconocer el sitio en que se levantaría el convento. Se llamaban fray Geroteo de San Pascual, fray Juan de Jesús María y fray Lorenzo de Santa Teresa, este último rrelixiosso lego maestro de ôbras. Por aquella fecha la construcción no había sido adjudicada a nadie, pero el provincial tenía preferencia a la hora de elegir maestro. De no hacerlo él sería el obispo el encargado de nombrarlo ${ }^{21}$.

\footnotetext{
${ }^{19}$ Lence-Santar, Mondoñedo: La Orden Tercera, pág. 1; del mismo autor Mondoñedo: El Convento de Alcántara, págs. 13-14; y Mondoñedo. El Convento de San Martín..., págs. 20-21, 91; José M. FernáNDEZ FERnÁndeZ, "Oposición de los franciscanos de Villaoriente a la construcción del Convento de Alcantarinos, en Mondoñedo”, Estudios Mindonienses, núm. 13 (1997), págs. 741-742.

${ }^{20}$ ACMon, Miscelánea, arm. 2, est. 1, leg. 8, núm. 16, s/f; AHPLu, PNM, Agustín de Rega y Peña, leg. 8266-6, fols. 140 r. $^{\circ}-140 \mathrm{v} .{ }^{\circ}$, y leg. 8232-1, fols. 3r. ${ }^{\circ}-4 v .^{\text {o }}$; también en dicho fondo notarial v. Juan Varela, leg. 7038-5, fol. 117r. ${ }^{\circ}$ y Juan Antonio de Villar y Rubiños, leg. 7383-2, 1727, fols. 44r. ${ }^{\circ}-45 v^{\circ}$; LENCE-SAntar, Mondoñedo: El Convento de Alcántara, págs. 49-50; Fernández Fernández, "Oposición...”, pág. 740.

${ }^{21}$ ACMon, Actas Capitulares, vol. 17, fols. 52v.o-54r.o; AHPLu, PNM, Agustín de Rega y Peña, leg. 8266-7, fol. 32r. ${ }^{\text {; }}$, del mismo fondo notarial v. Juan Varela, leg. 7038-5, fols. 117v. ${ }^{\circ}-121$ r. $^{\text {o }}$ LENCE-SANTAR, Mondoñedo: La Orden Tercera, pág. 1; y Mondoñedo: El Convento de Alcántara, pág. 50. Respecto a la cantidad de dinero sobredicha, el padre Flórez indicó que la inversión total del obispo en el convento fue
} 
Los terrenos sobre los que se erigiría el cenobio se encontraban en una suave loma al oeste de la ciudad, extramuros pero inmediatos a la muralla, y recibían el nombre de Carroceira y del Rosal. El primero lo había ofrecido el regidor perpetuo Francisco Antonio Luaces y Somoza, y tras inspeccionarlo los mencionados frailes, inclusive el maestro de obras fray Lorenzo, concluyeron que no contaba con la capacidad suficiente para albergar el convento. De ahí que necesitasen del contiguo del Rosal, que consiguieron gracias a la compra de Muñoz ${ }^{22}$. Estos primeros frailes llegados en septiembre de 1727 se quedaron en la urbe, y a ellos se sumaron otros hasta el mes de diciembre. En este tiempo fueron acogidos en el Palacio Episcopal y en las viviendas de algunos canónigos. Desde entonces y durante los tres años que duró la construcción del convento se instalaron en una amplia casa cedida generosamente por un vecino. La vivienda se encontraba en la actual Rúa José María Pardo, y a los frailes les resultó muy cómoda no solo por su gran tamaño, sino porque albergaba la capilla de Nuestra Señora de la Concepción, que de manera provisional hizo las funciones de iglesia conventual ${ }^{23}$.

\subsection{Inicio e interrupción de las obras}

Según Lence-Santar las obras se iniciaron en septiembre de 1727 una vez reconocidos los terrenos. En octubre comenzó a extraerse piedra de las canteras, y desde entonces y hasta 1728 se hizo un importante acopio de materiales sin que

de 14.000 ducados, Henrique Flórez, España Sagrada. Theatro Geographico Historico de la Iglesia de España. Origen, divisiones, y limites de todas sus Provincias. Antiguedad, Traslaciones, y estado antiguo y presente de sus Sillas, con varias Disertaciones criticas. Tomo XVIII. De las Iglesias Britoniense, y Dumiense, incluidas en la actual de Mondoñedo, Madrid, Antonio Marín, 1764, pág. 275. Este dato lo tomó de las anotaciones de Francisco A. VillaAmil y SaAVEDra, Memorias para la historia de la Santa

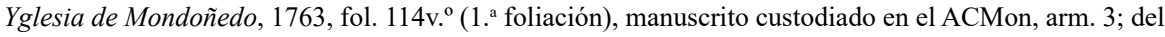
mismo autor v. Noticias de la santa Ygl. ${ }^{a}$ de Mondoñedo, s.a., fols. $105 \mathrm{r}^{\circ}-105 \mathrm{v} .^{\circ}$, manuscrito custodiado en la Biblioteca Nacional de España.

22 AHPLu, PNM, Agustín de Rega y Peña, leg. 8266-7, fols. 31r. ${ }^{\circ}-32 v^{\text {o }}$; del mismo fondo notarial v. Juan Antonio de Villar y Rubiños, leg. 8230-3, fols. 234r. ${ }^{\circ}-239 v .^{\circ}$, y leg. 7383-2, 1728, fol. 6v. ${ }^{\text {; }}$, LENCE-SANTAR, Mondoñedo: El Convento de Alcántara, págs. 53-54. A mediados del siglo XX todavía existía en la antigua biblioteca conventual una piedra de granito de 0,8 por 0,65 metros cuya inscripción aludía a la cesión de los terrenos por parte de los Luaces en 1727, Santos San Cristóbal Sebastián, "Convento de San Pedro de Alcántara", Cuadernos del Museo Mindoniense, núm. 12 (1986), pág. 13; Fernández VILlalba y SAN CRistóbal Sebastián, El convento..., págs. 9-10. El Cabildo también contaba con alguna propiedad en el Rosal, pero permitió que la ocupasen a cambio de una compensación, CAL PARDo, Episcopologio..., pág. 694.

${ }^{23}$ Lence-Santar, Mondoñedo: El Convento de Alcántara, págs. 62-63. Durante los tres años que los frailes se alojaron en aquella casa aprovecharon para hacer en la capilla un altar dedicado a San Juan Bautista, Lence-Santar, Mondoñedo. El Convento de San Martín..., págs. 89-90, 92-93. De ahí que a inicios del siglo XX se le conociese como capilla de San Juan. Esta se destruyó en 1918, Andrés GarCía Doural, "La capilla de la Concepción de Mondoñedo", Miscelánea Mindoniense [blog] 20 (enero.2018), disponible en <www.blogoteca.com/doural/> [Consulta: 28/06/2019]. 
por ello se hubiese levantado nada. Todas estas labores fueron dirigidas por el maestro fray Lorenzo de Santa Teresa-cuestión sobre la que volveremos luego-, quien en ciertos momentos contó con la ayuda de algún colega, pues a finales de noviembre de 1727 llegaron a Mondoñedo varios alcantarinos por orden del provincial para colaborar en la construcción. Uno era el maestro de obras fray Manuel de la Asunción, quien trabajó junto a fray Lorenzo. Con él vinieron el predicador fray Antonio de Jesús María en calidad de sobrestante y el donado Juan de San Pedro de Alcántara como limosnero. Además, el síndico del convento, Pedro de Leiva, contrató al maestro herrero de Ribadeo Isidro Pérez Villaamil para que se ocupase del hierro necesario en el cenobio ${ }^{24}$.

Todo parece indicar que entre octubre de 1727 y mediados de 1728 el acopio de materiales transcurrió con total normalidad, y que en febrero de este último año ya se llevaban gastados 4.000 ducados en esta labor ${ }^{25}$. De hecho, el 4 de mayo, víspera de la muerte del obispo Muñoz, su sobrino Leiva se había concertado con el maestro Sebastián Díaz Ribadeneira y con don Andrés López Traveso Baamonde, vecinos ambos de Mondoñedo, para que condujesen hasta el Rosal la cantería extraída en la cercana parroquia de Viloalle, cobrando 3 reales y 1 cuartillo por cada piedra. Hasta la fecha se habían encargado de su transporte algunos labradores a los que se les pagaba con dinero procedente de limosnas ${ }^{26}$. En este sentido cabe destacar que la generosidad del pueblo mindoniense resultó fundamental para hacer realidad el convento, pues a lo largo de 1728 numerosos vecinos contribuyeron a financiarlo donando tierras y otros bienes, y la ayuda llegó incluso de feligreses pertenecientes a la diócesis de Oviedo ${ }^{27}$.

Pero en aquel 1728, concretamente en el mes de febrero, la situación se complicó para los alcantarinos. Por un lado no les quedó más remedio que aceptar un acuerdo con el Cabildo para poder erigir su casa. El origen de esta concordia se remontaba a la semana siguiente de haber firmado fray Juan Muñoz la fundación, y en ella los capitulares obligaban a los descalzos a pagar el diezmo en caso de que llegasen a poseer bienes raíces. Les prohibían celebrar funerales en el convento sin la autorización del canónigo fabriquero. También portar cruces e insignias propias cuando participasen en entierros y procesiones. Y por último habrían de

\footnotetext{
${ }^{24}$ Lence-Santar, Mondoñedo: La Orden Tercera, pág. 5; también Mondoñedo: El Convento de Alcántara, págs. 15-16, 50; y Mondoñedo. El Convento de San Martín..., págs. 90-91, 96.

${ }^{25}$ AHPLu, PNM, Agustín de Rega y Peña, leg. 8232-1, fol. 119v. ; AMMon, Carp. 944, Libro de Actas (1726-1730), 1728, s/f.; Lence-SAntar, Mondoñedo. El Convento de San Martín..., págs. 92, 96.

${ }^{26}$ AHPLu, PNM, Juan Antonio de Villar y Rubiños, leg. 8231-1, fols. 142r. ${ }^{\circ}-142 \mathrm{v} .{ }^{\circ}$.

27 AHPLu, PNM, Juan Antonio de Villar y Rubiños, leg. 8231-1, fols. 61r. ${ }^{\circ}-62 v^{\circ}{ }^{\circ}, 75 r^{\circ}{ }^{\circ}-78 v^{\text {o }}$; LENCE-SAN- $^{-}$ TAR, Mondoñedo: El Convento de Alcántara, págs. 15-16. Acerca de las innumerables donaciones que recibió el convento desde finales de la década de 1720 y en los decenios siguientes v. LENCE-SANTAR, Mondoñedo: La Orden Tercera, págs. 2-4; y Mondoñedo: El Convento de Alcántara, págs. 49-70. También LóPEz, “Convento...", págs. 80-81, 86-89.
} 
permitirles el acceso al templo conventual cuando quisiesen formar una procesión hasta allíi ${ }^{28}$. Pero el verdadero escollo para los alcantarinos fueron sus hermanos franciscanos de Vilalourente, quienes se acogieron a una de las cláusulas rubricadas meses atrás por la cual no podrían construir nada sin la bula confirmatoria de Roma, y aprovecharon su incumplimiento para interponer un pleito y pedir a Muñoz que detuviese el transporte de materiales hasta el Rosal. El 5 de mayo falleció el obispo sin ver remediada esta desagradable situación ${ }^{29}$. Y a finales de mes, estando las obras paralizadas, el Ayuntamiento permitió que los descalzos encañasen hasta el Rosal el agua de la conducción que recientemente había promovido dicho prelado ${ }^{30}$.

\subsection{Conclusión del convento durante el episcopado de Sarmiento (1729-1731)}

Los meses transcurrieron sin que nada hubiese cambiado y 1729 se inició con la situación heredada del año anterior. La bula no llegaba de Roma, el nuevo obispo todavía no había ocupado la silla, los terceros de Os Picos tampoco daban su brazo a torcer, y el gasto en materiales acarreados se cifraba en 6.000 ducados sin que por ello se hubiese levantado nada ${ }^{31}$. Ante semejante bloqueo los alcantarinos decidieron hacer caso omiso de la cláusula pactada con los terciarios y retomaron la construcción. De poco les sirvió, pues el 16 de abril un notario comunicó a pie de obra a los alarifes, aparejadores y demás oficiales que allí trabajaban, que los frailes de Vilalourente les exhortaban a cesar con la pared que estaban levantando. Esta notificación la enviaban a instancias del juez apostólico de Lugo, quien había estimado interrumpir las obras mientras no se fallase el pleito. Por suerte conocemos la identidad de los canteros a quienes advirtió el escribano. Entre los allí presentes se hallaban Sebastián Díaz Ribadeneira, Salvador Fernández Villabeirán, Antonio Méndez, Manuel Malleza, Manuel do Rego y Salvador Valiño, vecinos todos de Mondoñedo. Y también fr. lorenzo lego, quien les asiste. Este dato confirma que fray Lorenzo de Santa Teresa dirigía las obras del convento tal y como había expresado Lence ${ }^{32}$.

\footnotetext{
${ }^{28}$ ACMon, Actas Capitulares, vol. 17, fols. 53v. ${ }^{\circ}-54 r^{\circ}$; AHPLu, PNM, Juan Antonio de Villar y Rubiños, leg. 7383-2, 1728, fols. 5r. ${ }^{\circ}-10$ r. $^{\text {; }}$ Lence-SANTAR, Mondoñedo: La Orden Tercera, págs. 1-2; FeRnáNDEZ Fernández, “Oposición...”, págs. 742-743; Cal PARdo, Episcopologio..., págs. 694-695.

29 AHPLu, PNM, Agustín de Rega y Peña, leg. 8232-1, fol. 119v. '; AMMon, Carp. 944, Libro de Actas (1726-1730), 1728, s/f.; Lence-Santar, Mondoñedo. El Convento de San Martín..., págs. 92, 95-97.

30 AMMon, Carp. 944, Libro de Actas (1726-1730), 1728, s/f; Lence-Santar, Mondoñedo: El Convento de Alcántara, pág. 15.

31 ACMon, Miscelánea, arm. 2, est. 1, leg. 8, núm. 7, s/f; AHPLu, PNM, Agustín de Rega y Peña, leg. 8232-2, fols. 1 r. $^{\mathrm{o}}-2 \mathrm{v} .^{\mathrm{o}}$.

32 AHPLu, PNM, Antonio Fernández Valledor, leg. 8147-2, fols. 19r. ${ }^{\circ}-19$ v. ${ }^{\circ}$.
} 
Los oficiales obedecieron y todo se detuvo. Solo la oportuna intermediación del Real Consejo a instancias del obispo fray Antonio Alejandro Sarmiento permitió su reanudación, y el 12 de agosto se colocó la primera piedra ${ }^{33}$. Tal era el temor que tenían los alcantarinos a que un nuevo revés les llevase a más litigios y suspensiones, que ese mismo día enviaron al Cabildo un memorial pidiéndole que no entorpeciese las obras ${ }^{34}$. Estas avanzaron durante el verano, época en que se tramitaron licencias para conducir por vía marítima la madera destinada a la construcción, que desembarcaba en el puerto de Ribadeo procedente de Asturias ${ }^{35}$. Pero a caballo entre el periodo estival y el otoñal se suspendieron por tercera vez. Esta nueva paralización se debió a la presión ejercida por los frailes de Os Picos, pues en octubre el Ayuntamiento trató de hablar con el obispo para que prosiguiesen tras su injusta y maliciosa oposicion ${ }^{36}$. Pero también tuvo parte de culpa el Cabildo, que ahora requería de una bula confirmatoria de la concordia firmada con los alcantarinos ${ }^{37}$, sin la cual no les permitiría establecerse como comunidad en el convento, ni tampoco fabricar yglesia ôratorio ni capilla alguna ni colocar el santissimo. Solo les dejaría cubrir el ttecho de la ôbra que ttienen prinzipiada, y guardar en ella los materiales ya listos para su fabrica para que no se malogren y desperdiçien con el rigor de los ttenporales ${ }^{38}$.

Por fortuna para los descalzos este mandato capitular fue soslayado por el obispo Sarmiento, quien el 4 de noviembre les permitió seguir con la construcción de las estancias conventuales ${ }^{39}$. El 13 de diciembre estas tocaron a su fin con la colocación de la última teja, quedando "solo" por edificarse la iglesia y la portería $^{40}$. En febrero de 1730 los alcantarinos recibieron otro golpe de suerte al acceder el Cabildo a que levantasen el templo sin haber recibido la bula. Podrían abrir sus cimientos y trabajar hasta abril, intervalo de tiempo en el que estimaban que se remitiese el documento desde Roma. Con todo, les advirtieron que si no llegaba

\footnotetext{
33 Lence-Santar, Mondoñedo: El Convento de Alcántara, pág. 16; y Mondoñedo. El Convento de San Martín..., págs. 98-99; Fernández FernÁndez, "Oposición...”, págs. 744, 748.

${ }^{34}$ ACMon, Actas Capitulares, vol. 17, fol. 111v.; CAL PARdo, Episcopologio..., págs. 744-745.

35 ACMon, Actas Capitulares, vol. 17, fols. 114r. ${ }^{\circ}-115 r^{\circ}$; AHPLu, PNM, leg. 8232-2, fols. 27r. ${ }^{\circ}-27 v^{\circ}{ }^{\circ}$

${ }^{36}$ AHPLu, PNM, Agustín de Rega y Peña, leg. 8232-2, fols. 36r. ${ }^{\circ}-37 v^{\circ}{ }^{\circ}$. Sobre este asunto véase más detalladamente FERnÁNDEZ FernÁNDEZ, “Oposición...”, págs. 744-748.

${ }^{37}$ El 5 de octubre de 1729 los capitulares y los descalzos concordaron financiarla, ACMon, Actas Capitulares, vol. 17, fol. 114r. ${ }^{\circ}$; AHPLu, PNM, Juan Varela, leg. 8274-1, fols. 11r. ${ }^{\circ}-12$ r. $^{\circ}$; CAL PARdo, Episcopologio..., pág. 745. Con buena parte de su costo corrió Carlos Maseda y Baamonde, canónigo y provisor del obispado mindoniense, abogado de la Real Audiencia y uno de los grandes benefactores del convento, Lence-SAntar, Mondoñedo: El Convento de Alcántara, págs. 51-52.

38 ACMon, Actas Capitulares, vol. 17, fols. 115r. ${ }^{\circ}-116$ r. $^{\circ}$; AHPLu, PNM, Juan Varela, leg. 8274-1, fols. 13r. ${ }^{\circ}, 15$ v. ; CAL PARDO, Episcopologio..., pág. 745.

39 FernÁndez Fernández, “Oposición...”, pág. 748.

${ }^{40}$ Lence-Santar, Mondoñedo: El Convento de Alcántara, pág. 16; y Mondoñedo. El Convento de San Martín..., pág. 99.
} 
este, las obras tendrían que paralizarse ${ }^{41}$. Quizá por ello aceleraron cuanto pudieron su edificación, concluyéndola en apenas dos meses, pues la ceremonia de colocación de la primera piedra tuvo lugar el 5 de marzo ${ }^{42}$, y tan solo seis semanas después la nueba yg. ${ }^{\text {la }}$ estaba casi para acabarse. Aun así la bula continuaba sin llegar, y ambas partes sabían que su retraso se debía al pleito con los frailes de Os Picos y a la muerte de Benedicto XIII. De hecho no habría forma de lograrla hasta la elección de un nuevo papa. Posiblemente por esta razón, y ante la insistencia de los alcantarinos, el Cabildo volvió a permitirles que reanudasen la edificación, en vista de que era lo más conveniente para la fábrica ya realizada y para los materiales que tenían preparados ${ }^{43}$.

A mediados de octubre llegó la bula que ratificaba las cláusulas entre los capitulares y los frailes del Rosal. Gracias a ella los canónigos aprobaron que estos pasasen a habitar el nuebo conuento que tienen fabricado, noticia que vuelve a confirmar que la casa monástica estaba terminada y habitable ${ }^{44}$. Allí se instalaron a inicios de enero de $1731^{45}$. Y en julio el guardián del cenobio solicitó al Cabildo que concurriese en procesión junto al obispo para instalar el Santísimo en su igle$\mathrm{sia}^{46}$. Esta ceremonia tuvo lugar el 5 de agosto. El encargado de trasladarlo desde la catedral fue fray Antonio Alejandro Sarmiento, a quien siguieron el cuerpo de capitulares, las autoridades locales y el pueblo mindoniense. Las funciones religiosas se prolongaron durante dos jornadas más, pero las profanas sobrepasaron la semana. En ellas hubo comedias, corridas de toros, juegos de sortija, disfraces, y fuegos de artificio ${ }^{47}$. El templo se puso bajo la advocación de la Virgen y de San Francisco, y debido a que se asentaba en unos terrenos conocidos desde antiguo como del Rosal, se le conoció como de San Francisco del Rosal o de Nuestra Señora del Rosal ${ }^{48}$. A partir de entonces la comunidad reglar comenzó a funcionar con total normalidad, integrándola en 1732 una quincena de miembros ${ }^{49}$.

\footnotetext{
${ }^{41}$ AHPLu, PNM, Juan Varela, leg. 8274-2, 1730, fol. 4r..

42 Este rito tuvo lugar a las cuatro y media de la tarde en el sitio que ocuparía el altar mayor, en donde se ubicó un altar portátil con un Crucificado de marfil regalado a la comunidad por una noble. A la función asistió el Cabildo, Lence-Santar, Mondoñedo: El Convento de Alcántara, págs. 16-17, 29, 60; y Mondoñedo. El Convento de San Martín..., págs. 99-100; LóPEz, “Convento...”, pág. 83.

${ }^{43}$ ACMon, Actas Capitulares, vol. 17, fols. 138r. ${ }^{\circ}-138 v^{\circ}$; AHPLu, PNM, Juan Varela, leg. 8274-2, 1730, fols. 4r. ${ }^{\circ}-5$ r. $^{\circ}$; CAL PARDo, Episcopologio..., pág. 745.

${ }^{44}$ ACMon, Actas Capitulares, vol. 17, fols. 155v. ${ }^{\circ}-156$ r. $^{\circ}$. En este archivo véase también Miscelánea, arm. 2, est. 1, leg. 8, núms. 4 y 5, s/f; CAL PARdo, Episcopologio..., págs. 695, 745.

45 AHPLu, PNM, Juan Varela, leg. 8274-2, 1732, fol. 24v.; Lence-SANTAR, Mondoñedo: La Orden Tercera, pág. 3; y Mondoñedo: El Convento de Alcántara, pág. 17.

46 ACMon, Actas Capitulares, vol. 17, fol. 173v. ; CAL PARdo, Episcopologio..., págs. 745-746.

${ }^{47}$ Lence-Santar, Mondoñedo: La Orden Tercera, pág. 3; y Mondoñedo: El Convento de Alcántara, pág. 17.

48 AHPLu, PNM, Lorenzo Prieto y Solloso, leg. 6262-5, fols. 3r. ${ }^{\circ}-3 \mathrm{v} .{ }^{\text {o }}$; ya se cita como El Rosal en una escritura de 1615, mismo fondo notarial, Juan Abad, leg. 7211-2, fol. 256r. ${ }^{\circ}$.

49 ACMon, Miscelánea, arm. 2, est. 1, leg. 8, núm. 20, s/f; AHPLu, PNM, Juan Varela, leg. 8274-2, 1732, fols. 28r. ${ }^{\circ}, 29 \mathrm{v} .^{\text {o. }}$ Lence-Santar, Mondoñedo: El Convento de Alcántara, pág. 18.
} 


\subsection{La capilla de la Venerable Orden Tercera}

De todos es sabido que los seglares de la Venerable Orden Tercera vivieron en la Galicia de los siglos XVII y XVIII un periodo de fuerte expansión, y que en muchas de sus fundaciones se vieron especialmente beneficiados por sus hermanos regulares, quienes cedieron parte de sus terrenos para que pudiesen asentarse en ellos ${ }^{50}$. Así ocurrió en Mondoñedo, cuya capilla de la V.O.T. se construyó anexa al templo alcantarino. Según Lence-Santar su establecimiento se debió al guardián del cenobio fray Isidro de San Joaquín, quien junto con otros miembros de su comunidad, alentó y convenció a la población local de lo útil que sería el instaurarla, quedando oficialmente fundada el 24 de febrero de 1734. El mismo autor indica que la capilla se edificó en 1731, y que la construyó el mismo maestro que había dirigido las obras del convento, es decir, fray Lorenzo de Santa Teresa ${ }^{51}$. Un par de documentos de 1738 y 1749 aclaran que el encargado de costear su edificación fue Ciprián Antonio Gutiérrez y Santiso, síndico del convento y mayordomo del obispo Sarmiento. Estos manuscritos no reseñan qué maestro la levantó ni en qué fecha, pero desde luego lo expresado por Lence-Santar parece tener sentido ${ }^{52}$.

\subsection{Adiciones a la fábrica original}

Resumiendo los hitos más significativos de los apartados anteriores, cabría destacar que en 1727 se fundó el cenobio. En 1729 se levantó su espacio habitacional. En 1730 se edificó la iglesia y al año siguiente la capilla de la V.O.T. Y en este mismo 1731 se dedicó el templo conventual y los frailes abandonaron la casa donde llevaban viviendo tres años para instalarse definitivamente en el Rosal. Entonces las principales estancias del complejo estaban construidas, pero con el paso de los años surgieron otras necesidades que obligaron a complementar las ya realizadas ${ }^{53}$.

Así pues, a mediados de la década de 1730 se llevaron a cabo obras de menor importancia en el flamante recinto, como el enjalbegado del convento y del templo,

\footnotetext{
${ }^{50}$ Alfredo MarTín GarCíA, "Predicación franciscana y asociacionismo seglar: las Terceras Órdenes gallegas en la Edad Moderna", en José Miguel Andrade Cernadas, Raquel Casal García y Roberto J. López López (eds.), Galicia monástica. Estudos en lembranza da profesora María José Portela Silva, Santiago de Compostela, Universidade de Santiago de Compostela, 2009, págs. 364-366.

${ }^{51}$ Lence-Santar, Mondoñedo: La Orden Tercera, págs. 3, 5.

${ }_{52}$ AHPLu, PNM, Juan Varela, leg. 8274-5, fol. 120r. ${ }^{\circ}$. En el mismo fondo notarial v. Francisco Antonio Fernández de Parga, leg. 7333-6, fols. 44r. ${ }^{\circ}-44 \mathrm{v}^{\circ}$; Lence-Santar, Mondoñedo: El Convento de Alcánta$r a$, págs. 61, 67-68.

${ }^{53}$ Por suerte la comunidad reglar no volvió a verse envuelta en litigios de suma importancia a la hora de aumentar el cenobio, pues aparte de lograr en 1730 la bula exigida por el Cabildo, en los dos años siguientes resolvió todas las diligencias, permisos y convenios tocantes al pleito con los franciscanos de Os Picos, AHPLu, PNM, Juan Varela, leg. 8274-2, 1732, fols. 18r. ${ }^{\circ}-29 v^{\circ}{ }^{\circ}$.
} 
la conclusión de un corredor, o la erección de tapias para el cercado de las huertas. En fecha incierta, aunque muy probablemente en esos años centrales del decenio, se construyó una aula contigua a la portería cuyo costo sobrepasó los 500 ducados. Se hizo a petición del obispo Sarmiento, quien había tratado con el provincial de los alcantarinos el erigir un espacio donde un lector de Artes pudiese instruir a los jóvenes mindonienses. Durante su episcopado también se edificó una enfermería con seis alcobas que costó 6000 reales. Esta se levantó entre noviembre de 1745 y la Semana Santa de 1746. Y en este último año se entarimó la capilla mayor, la sacristía y la sala capitular ${ }^{54}$.

Otro benefactor de la casa alcantarina fue el obispo Carlos Riomol y Quiroga. En el tiempo en que rigió la diócesis (1752-1761) costeó en su totalidad una nueva cocina, invirtiendo en ella 3500 reales aproximadamente ${ }^{55}$. También durante su mandato, concretamente en septiembre de 1754, el Ayuntamiento donó 500 reales a los frailes para que diseñasen unas nuevas escaleras de acceso a la iglesia y a la capilla de la V.O.T., pues muchos vecinos se habían quejado de las dificultades que tenían para subirlas dada la altura de los peldaños ${ }^{56}$. Una de las nuevas escalinatas se construyó desde el antiguo Pazo de los Villapol -hoy sigue en pie-hasta la portada reglar. Junto al comienzo de la escalera se edificó una diminuta capillita con su escaparate dorado, en cuyo interior se guardaba una imagen de la Piedad. Mientras que en la cima de la escalinata se dispuso una efigie de san Francisco labrada en piedra ${ }^{57}$. Tiempo después, a principios de la década de 1770, se aumentó el tamaño de la cárcel conventual o casa de disciplina ${ }^{58}$.

\subsection{La autoría del convento}

En la primera década del siglo XX el erudito Lence-Santar manifestó que el convento del Rosal había sido construido - que no proyectado- por fray Lorenzo de Santa Teresa, un maestro de obras llegado a Mondoñedo en 1727 procedente del convento alcantarino de Villamañán (León), en el cual había edificado una enfermería. A este personaje lo confundió con un tal fray Lorenzo de Santa Rosa ${ }^{59}$. Y en esta errata persistió José Couselo Bouzas, quien además

\footnotetext{
${ }^{54}$ Lence-Santar, Mondoñedo: El Convento de Alcántara, págs. 18, 20, 67-68.

55 Lence-SAnTar, Mondoñedo: El Convento de Alcántara, págs. 21-22, 69.

${ }_{56}$ AMMon, Carp. 949, Libro de Actas (1751-1755), 1754, fols. 85v. ${ }^{\circ}-86$ r. $^{\circ}$.

${ }^{57}$ Los Villapol ya habían cedido parte de sus huertas para que los frailes pudieran ensanchar el atrio conventual, Lence-Santar, Mondoñedo: El Convento de Alcántara, págs. 21, 52, 60-61.

${ }^{58}$ Lence-Santar, Mondoñedo: El Convento de Alcántara, pág. 22.

59 Lence-Santar, Mondoñedo: El Convento de Alcántara, pág. 15. Nada hemos hallado en la escasa bibliografía del convento de Villamañán acerca de fray Lorenzo de Santa Teresa. Sobre este cenobio todavía resulta útil acudir a Teodoro DomíNGUEZ de VALDEÓN, El libro de Villamañán. Guía eclesiástica, geográfica, histórica, biográfica, bibliográfica, y turística de esta ilustre villa, León, Diputación Provincial, 1928.
} 
le otorgó a este segundo Lorenzo unos pasajes biográficos que en opinión de Paula Pita Galán forjaron un personaje ficticio ${ }^{60}$. Lence añadió que buena parte de las empresas urbanísticas patrocinadas por el obispo Sarmiento en Mondoñedo, tales como el puente de San Lázaro, el santuario de Los Remedios, o el Palacio del Buen Aire en Masma, habían sido dirigidas por el lego alcantarino ${ }^{61}$. Aunque acostumbraba a citar las fuentes que interpretaba y transcribía, en este caso nunca reseñó de dónde extrajo tales datos pese a reiterar en varias ocasiones dicha atribución. La historiografía posterior no solo no puso en tela de juicio su afirmación, sino que además engrandeció la figura del lego concediéndole la categoría de tracista de todas estas obras, e incluso de otras posteriores ideadas en el episcopado de Sarmiento (1728-1751), caso del Hospital de San Pablo o del edificio de la Cárcel, ambos en el barrio de Los Remedios ${ }^{62}$. Incluso se le ha atribuido la traza del retablo mayor de la capilla de la V.O.T., aduciendo similitudes con la arquitectura y la retablística de la zona de León $\mathrm{y} \mathrm{Astorga}^{63}$.

Por nuestra parte, tras revisar todos los protocolos notariales, libros de actas municipales y capitulares, libros de cuentas y otra mucha documentación perteneciente a este episcopado, en ningún caso podemos confirmar tales atribuciones salvo la del puente de San Lázaro, que efectivamente diseñó y dirigió fray Lorenzo entre 1734-1735. De todas las obras a él asignadas, esta es, y con diferencia, la de menor complejidad, pues no deja de ser un pequeño puentecillo de dos arcos sobre un río de escaso caudal. La verdadera impresión que dejan los manuscritos que citan al lego, es la de un maestro de no demasiada enjundia que entre 1727 y 1737 estuvo en Mondoñedo dirigiendo obras como la del convento o la del puente, y a mayores, haciendo arreglos de fontanería o elaborando peritajes de calzadas públicas o de viviendas de particulares ${ }^{64}$. Dicho lo cual, que este personaje fuese quien diseñó el cenobio es solo una mera posibilidad. Únicamente podemos confirmar que dirigió sus obras y que allí se emplearon cuadrillas de canteros locales ${ }^{65}$.

\footnotetext{
${ }_{60}$ José Couselo BouZas, Galicia artística en el siglo XVIII y primer tercio del XIX, Compostela, Seminario, 1932, pág. 41; Paula PITA GALÁN, Los frailes arquitectos del siglo XVIII en Galicia: trayectoria artística de los maestros regulares de las órdenes de San Benito, San Francisco y Santo Domingo, Tesis Doctoral, Santiago de Compostela, Universidade de Santiago de Compostela, 2019, págs. 151-152, 897.

${ }^{61}$ Lence-Santar, Mondoñedo: El Santuario..., pág. 13; del mismo autor Mondoñedo: La Orden Tercera, pág. 5.

${ }^{62}$ Vigo Trasancos, "La ciudad...”, págs. 536-537, 541-543, 547, 549.

${ }^{63}$ Novo SÁnchez, "Retablos...”, pág. 286.

${ }^{64}$ Todos los datos que hemos hallado sobre la figura de fray Lorenzo de Santa Teresa han sido cedidos a la investigadora Paula Pita Galán, quien los ha recogido dentro de su magnífica tesis doctoral. PITA GALÁN, Los frailes..., págs. 898-901.

${ }_{65}$ Aunque el citado Manuel Malleza era oriundo de Avilés, AHPLu, Protocolos Notariales, Ribadeo, Rosendo Martínez, leg. 1920-8, fol. 3r. ${ }^{\circ}$.
} 


\section{DesCRIPCiÓN DEL CONVENTO}

\subsection{Iglesia, capilla de la V.O.T. y dependencias comunitarias: el triunfo de la austeridad}

Como dijimos con anterioridad, el convento se ubicó sobre una loma extramuros cercana a la muralla y a la calle inmediata, conocida entonces como de Santo Domingo o de Batitales -hoy Leiras Pulpeiro-. El conjunto quedó vertebrado por la iglesia (fig. 5). En ella la orientación de la capilla mayor se dirigió hacia el suroeste, obviando así la canónica disposición al este. Esta extraña situación seguramente se debió a que la comunidad alcantarina habría querido que su convento mirase hacia el núcleo urbano. De hecho, a los pies del templo, en la zona más cercana al caserío, se ubicó la portería. A esta razón hay que añadir que en el momento en que se fundó el cenobio, los frailes todavía no poseían todos los terrenos que los mindonienses les fueron cediendo durante las dos décadas siguientes. Por lo demás, hacia el sureste de la iglesia se construyeron las depen-

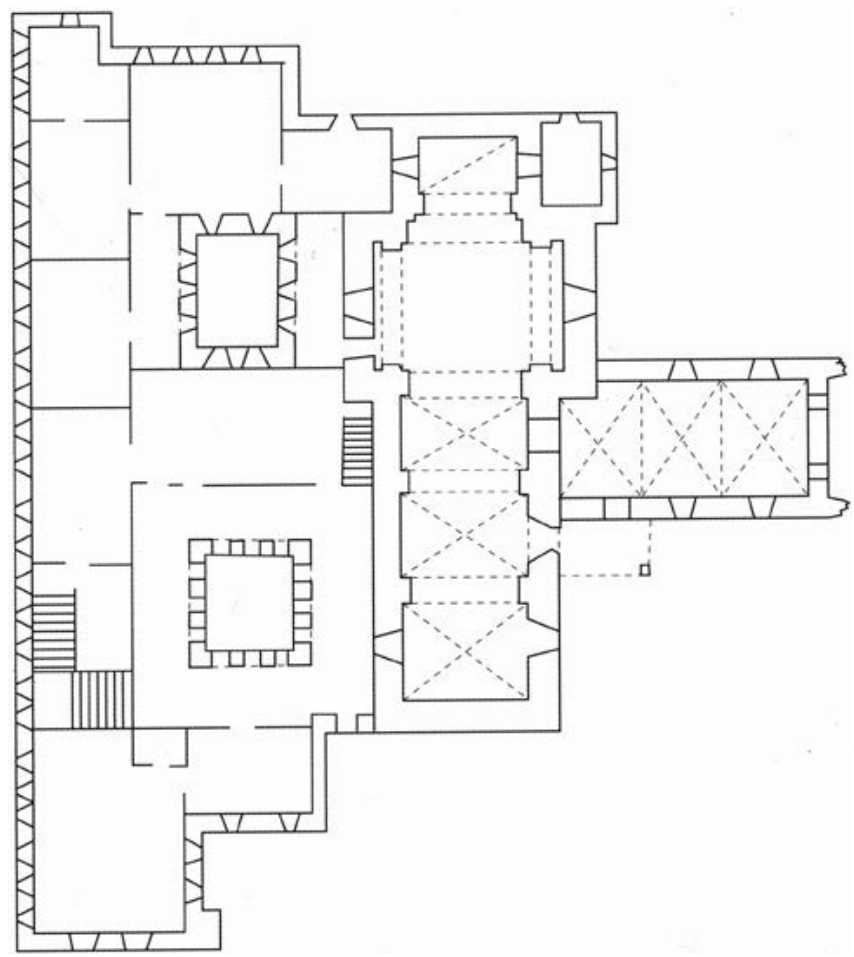

Fig. 5. Planta del antiguo convento de San Francisco del Rosal. Tomada de Laura Río Ramos,

"San Pedro de Alcántara", en Francisco Rodríguez Iglesias (dir.), Mosteiros e conventos da Península Ibérica. Galicia, vol. 6, A Coruña, Hércules, 2008, pág. 73. 
dencias comunitarias y se ubicaron las huertas. Al otro lado del templo se anexó perpendicularmente la capilla de la V.O.T., generando estos recintos un compás ante sí -hoy Praza Jaime Cabot- (fig. 3). En el ángulo de unión de ambos se conserva el pórtico que cobija las entradas a sendos templos. Este atrio porticado ya existía originalmente, pues aparece descrito en un documento de $1749^{66}$. Su cubierta la sostienen un par de pilares toscanos y octogonales, aunque solo el exento parece primitivo, pues el embebido junto a la puerta de la iglesia ha sido rehecho en estilo en fechas no muy lejanas. Ambas portadas son de enorme sencillez y presentan un formato adintelado. La del templo tiene sobre la clave el escudo del obispo fundador fray Juan Muñoz, y encima una sencilla hornacina hoy vacía, que en origen albergaría la imagen de san Francisco o de la Virgen por ser las advocaciones titulares del convento.

El templo presenta una planta de cruz latina y su única nave se divide en tres tramos, siguiéndole un crucero de brazos mínimamente desarrollados y una cabecera recta. Los referidos tramos de la nave se articulan con pilastras toscanas sobre cuyo capitel montan arcos fajones de medio punto. La nave y la capilla mayor cuentan con bóvedas de aristas; los brazos del crucero con bóvedas de cañón; mientras que el tramo central del mismo con una bóveda vaída. El presbiterio comunicaba con un par de estancias rectangulares que bien pudieran ser dos sacristías, o, si acaso, una sacristía y la sala capitular. Por lo demás, el alzado interior del templo sorprende por su rotunda sencillez. No existe elemento decorativo alguno y las paredes solo se ven animadas por las pilastras o por la imposta que une los capiteles (fig. 6).

La capilla aneja de la V.O.T. cuenta con una planta rectangular formada por una nave de tres tramos y un testero de perfil recto ${ }^{67}$. A diferencia de la iglesia, sus muros no presentan ni pilastras ni ménsulas, con lo cual, las bóvedas de aristas se funden con la pared hasta alcanzar la imposta sin mayor punto de apoyo (fig. 8). Originalmente este recinto estaba conectado con el templo gracias a una puerta conducente al tramo de la nave inmediata al crucero, pero en la actualidad se halla cegada. También en sus primeros tiempos contaba con una sacristía unida axialmente a la capilla mayor, en cuya fachada abierta al compás se erguía una sencillísima espadaña con un vano carpanel rematado por un pináculo con bola (fig. 3). Este edificio debió de modificarse a partir de 1888, pues entonces se aprobó concederle una nueva altura. Hacia 1911-1913 se renovó para albergar la vivienda de los padres de la Congregación de la Pasión. La obra fue delineada y dirigida

\footnotetext{
${ }^{66}$ AHPLu, PNM, Francisco Antonio Fernández de Parga, leg. 7333-6, fols. 44r. ${ }^{\circ}-44 \mathrm{v} .^{\text {o }}$.

${ }^{67}$ Los dos arcosolios de medio punto que aparecen a ambos lados del presbiterio no corresponden con la fábrica primitiva, sino que fueron perforados tras aprobarlo la V.O.T. en octubre de 1808, LENCE-SANTAR, Mondoñedo: La Orden Tercera, pág. 8.
} 


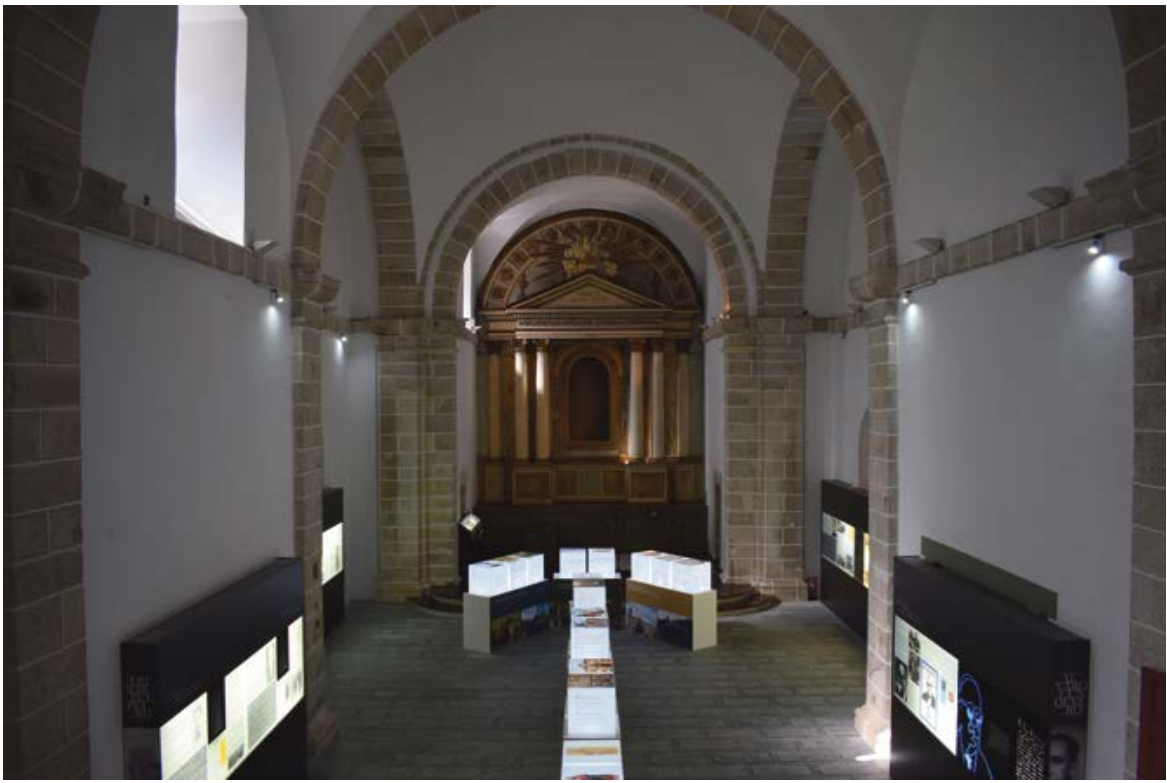

Fig. 6. Interior de la antigua iglesia de San Francisco del Rosal -hoy Centro Cultural da Alcántara. Centro de Interpretación do Camiño Norte-Vista desde su tribuna. (Fotografía del autor).

por un religioso pasionista, Gabriel de la Dolorosa ${ }^{68}$, y hoy día es el Albergue Público de Mondoñedo ${ }^{69}$.

El carácter desornamentado y austero de la arquitectura descrita no solo se circunscribe al interior de los espacios litúrgicos, sino que se manifiesta de igual forma en el exterior, sin que en los muros del templo, en los de la capilla de la V.O.T., o en los del resto de dependencias conventuales existan columnas, pilastras o impostas que los articulen. Como tampoco elementos de adorno. Todo es modestia, sobriedad y sencillez. De ahí que coincidamos con Alfredo Vigo al considerar que esta fábrica esencialísima carece casi de estilo reconocible. No cabe

\footnotetext{
${ }^{68}$ Lence-Santar, Mondoñedo. El Convento de San Martín..., pág. 50; y Del Obispado de Mondoñedo, Mondoñedo, 1915, t. 3, págs. 89-90; Santos SAn Cristóbal Sebastián, La ciudad de Mondoñedo, Lugo, Caja de Ahorros de La Coruña y Lugo, 1975, pág. 41. Andrés García Doural, "La nueva residencia de los P.P. de Alcántara”, Miscelánea Mindoniense [blog] 29 (julio.2012), disponible en <www.blogoteca.com/ doural/> [Consulta: 14/01/2018]. A partir de entonces la primitiva espadaña se perdió y se dispuso otra sobre la entrada a la capilla de la V.O.T., tal y como se aprecia en distintas fotografías. Hoy día tampoco se conserva esta.

${ }^{69}$ El edificio se rehabilitó en 2002-2003 siguiendo un proyecto de Ernesto Cruzado Estévez. José Manuel García Iglesias (dir.), Antonio Garrido Moreno (aut.), Arquitecturas no Camiño, 1994-2004. Colexio Oficial de Arquitectos de Galicia (COAG). Santiago de Compostela 30 xullo / 31 outubro 2004, Santiago de Compostela, Xunta de Galicia, 2004, págs. 308-311, 482.
} 
duda de que los valores de pobreza promulgados por los alcantarinos trascienden aquí a su arquitectura ${ }^{70}$. El propio Muñoz había manifestado en repetidas ocasiones previa la construcción del cenobio que la sencillez de estos frailes casaba a la perfección con su ideario espiritual, y también con las posibilidades económicas que ofrecía una ciudad como Mondoñedo, carente de un clero, de una nobleza, o de una burguesía lo suficientemente pudientes como para patrocinar fastuosos monasterios $^{71}$.

Esta simplicidad tan notoria se manifiesta hasta en la fachada. Bien es verdad que resulta imposible determinar con exactitud cómo era originalmente, pues en la mitad inferior de su lienzo se incrustaron distintos inmuebles en los siglos XIX y $\mathrm{XX}^{72}$. Pero viendo la parte superior indemne a estos añadidos, y conocida la fisionomía del resto del convento, no cabe imaginarse otra cosa que no fuese un frontispicio de lo más anodino. De lo que se conserva hoy día se puede apreciar un frente raso sin articulación ni ornato alguno, roto simplemente por una ventana rectangular. El ritmo de su cubierta a dos aguas se torna horizontal para recibir la espadaña, que presenta un vano oval en su base al que sigue un arco de medio punto destinado a albergar la campana. Este cuerpo se anima con un par de impostas, un frontón de remate, y cinco pináculos de base cuadrangular, tronco piramidal y bola. Su modelo recuerda a algunas espadañas de la provincia de León $^{73}$.

Como se dijo anteriormente, todas las estancias comunitarias del cenobio se situaban anejas al lado del Evangelio del templo. Y de este conjunto solo pervive un claustrillo junto a los pies del mismo (comp. figs. 4 y 7). Tiene planta cuadrada y en su piso bajo presenta tres arcos carpaneles sobre impostas, todo ello de cantería. Su segunda altura cuenta también con arcos apainelados montados en los anteriores. Estos quizá sean de mampostería enlucida. Este claustro no comunicaba con la iglesia. Todo lo contrario sucedía con el claustrillo desaparecido, inmediato al crucero. Respecto al resto de estancias perdidas poco se puede decir dada la falta de documentación y de fuentes gráficas originales. Solo las viejas fotografías de principios del siglo XX nos confirman que el cierre suroriental del

\footnotetext{
70 Vigo Trasancos, “La ciudad...”, pág. 541.

71 Este aspecto ya fue recalcado por otros autores, que incluso transcribieron las palabras de Muñoz relativas a que los religiosos descalzos eran los más convenientes y a propósito, por su parco alimento, vestuario y gastos de casa e iglesia, con las más oficinas de dicho convento, FERnández FERnández, "Oposición...”, pág. 740; CAL PARDo, Episcopologio..., pág. 693. Sobre los aspectos sociales, políticos y económicos de la ciudad y provincia de Mondoñedo en Época Moderna v. Pegerto SAAvedra FERnÁndez, Economía, Política y Sociedad en Galicia: la provincia de Mondoñedo, 1480-1830, Madrid, Xunta de Galicia, 1985.

${ }^{72}$ Actualmente el edificio que tiene empotrado es el del Juzgado de Primera Instancia e Instrucción n.$^{\circ} 1$.

${ }^{73}$ Sobre este particular v. Emilio Morais VAlLejo, Aportación al barroco en la provincia de León. Arquitectura religiosa, León, Universidad de León, 2000, págs. 172-175.
} 


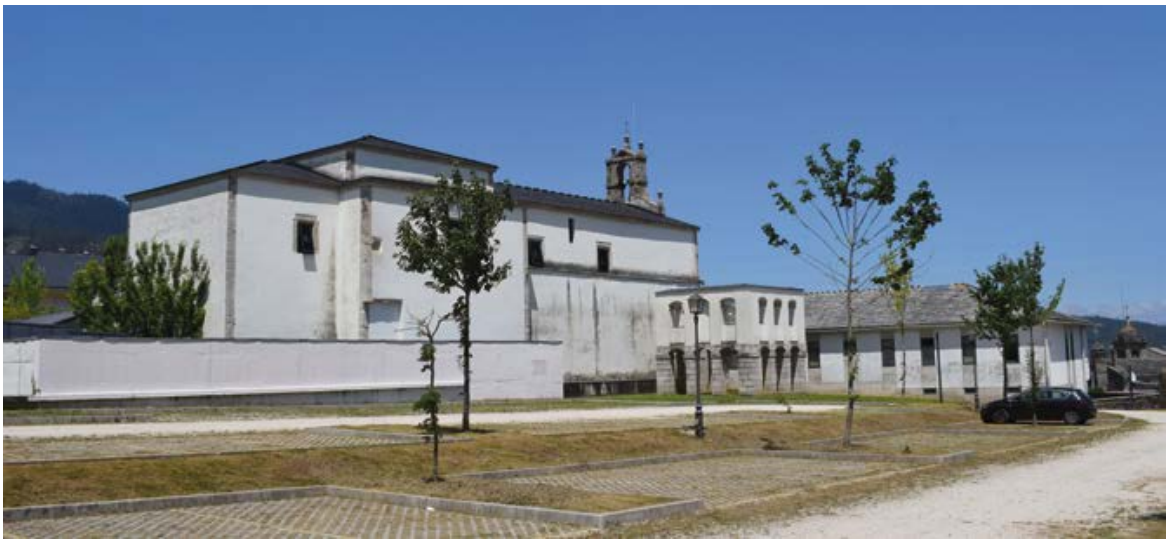

Fig. 7. Actual aparcamiento municipal donde antaño se hallaban las dependencias comunitarias del convento. Al fondo se aprecia el único claustrillo que se conserva. (Fotografía del autor).

convento presentaba una sencilla fachada de dos alturas, animada únicamente por dos filas de ventanas cuadrangulares, no existiendo en este largo muro elemento articulador o adorno alguno (figs. 2 y 4 ).

\subsection{El convento y la arquitectura alcantarina}

El establecer un modelo ideal o prototípico de convento alcantarino es en sí mismo un equívoco, pues las decenas de fundaciones que se hicieron a lo largo y ancho de la Península Ibérica responden a distintos fines, momentos históricos, patrocinadores y posibilidades económicas. Además, muchos de estos conjuntos nos resultan prácticamente desconocidos por haber desaparecido o por haber llegado a nuestros días en un estado muy diferente del primigenio. Esto se debe, en buena parte, a la conjunción formada por su habitual ubicación en el medio rural y a la exclaustración de 1835. Dicho de otro modo, si muchos de los edificios conventuales de distintas órdenes se salvaron de la piqueta a partir de aquella fecha, fue porque su situación en el medio urbano los convirtió en lugares idóneos donde establecer las nuevas sedes de las antiguas parroquias. Pero la localización de tantos monasterios alcantarinos en páramos, montes y campos despoblados, supuso todo lo contrario. Pese a todo, sí han sobrevivido una serie de conventos y una ingente documentación que contribuye al conocimiento de los espacios litúrgicos y comunitarios de los mismos, y en ellos se aprecian ciertas señas de identidad a las que el cenobio de Mondoñedo no fue ajeno.

Partiendo pues de la base de que no todas las particularidades de esta arquitectura se dan en el convento del Rosal, conviene al menos citar aquellas que sí coinciden en su sentido más genérico. Para empezar, se instaló en un arrabal 
inmediato al núcleo urbano y en una zona de huertas próximas a un arroyo. $\mathrm{Su}$ iglesia se diseñó partiendo de una planta de cruz latina de brazos escasamente desarrollados. Contaba con dos claustros de diminutas dimensiones, impropios de cualquier Orden que no fuese la alcantarina. También carecía de torre campanario, y en su lugar, como era habitual, se dispuso una simple espadaña. Por último, se edificó con materiales austeros y careciendo de ornamentación tanto en el interior como en el exterior ${ }^{74}$.

Por increíble que parezca, el respeto a ciertas generalidades de la arquitectura descalza permite trazar en sus líneas más esenciales un paralelismo entre la planta del convento mindoniense y la del homólogo de la ciudad de Sevilla, levantado a mediados del siglo XVII. De este solo se conserva la iglesia y la capilla de la Venerable Orden Tercera. También aquí la capilla seglar se unía perpendicularmente al templo, formando ambos recintos un compás y compartiendo el pórtico que cobijaba sus entradas. Además, al otro lado de la iglesia se situaban el resto de dependencias comunitarias, un par de claustros y la huerta. El convento hispalense, a diferencia del de Mondoñedo, no se irguió sobre unos solares expeditos, sino ocupando una manzana urbana. De ahí que estas semejanzas en sus plantas llamen todavía más la atención ${ }^{75}$.

\subsection{Los primitivos espacios litúrgicos: altares y devociones}

Concluido el templo en 1730, las donaciones de los devotos se destinaron a financiar el mobiliario litúrgico. Las noticias que aluden a sus primitivos altares son un tanto vagas. No obstante, conviene al menos reseñar cuáles eran y dónde se ubicaban. Indudablemente, la comunidad puso su mayor empeño en realizar el retablo mayor, que poco después de la exclaustración fue desmembrado y trasladado hasta la iglesia parroquial de Santiago de Lindín (Mondoñedo) ${ }^{76}$. Se

\footnotetext{
${ }_{74}$ Francisco A. Hipólito OJalvo, "El patrimonio arquitectónico alcantarino de la provincia de Cáceres", San Pedro de Alcántara, hombre universal. Congreso de Guadalupe, 1997, Guadalupe, Ediciones Guadalupe, 1998, pág. 507.

75 Véase una descripción morfológica del antiguo convento alcantarino de Sevilla y una planta decimonónica del mismo en Alberto Fernández GonzÁlez, "Fuentes gráficas para el estudio de tres edificios históricos de Sevilla: las plantas de los conventos de la Santísima Trinidad, San Francisco de Paula y San Pedro de Alcántara", De Arte, núm. 11 (2012), págs. 155-166. Para una síntesis de las características espaciales y arquitectónicas de los conventos de la descalcez v. Carmen AraYA IgLeSIAS, Germán GraU LoвATo, "Monumentos histórico-artísticos alcantarinos en la provincia de Badajoz", San Pedro de Alcántara, hombre universal. Congreso de Guadalupe, 1997, Guadalupe, Ediciones Guadalupe, 1998, págs. 509-588; de los mismos autores v. "Lugares alcantarinos en la provincia de Badajoz", Revista de Estudios Extremeños, 57, núm. 1 (2001), págs. 49-72.

${ }^{76}$ Lence-Santar, Mondoñedo: El Convento de Alcántara, págs. 25-26; José Manuel GonzÁlez ReboRedo, Santos San Cristóbal Sebastián, Nicanor Rielo Carballo, Elías Valiña Sampedro, Inventario artístico de Lugo y su provincia, t. 3, Madrid, Ministerio de Cultura, 1980, págs. 410-411. Existe una fotografía del mueble en Xe FreYre, Mondoñedo, León, Everest, 1990, pág. 93.
} 
ignora su autoría ${ }^{77}$. Solo se sabe que tenía cuatro columnas salomónicas y ocho imágenes. Y también que hubo de ejecutarse entre 1731-1736, pues la primera data corresponde a la dedicación del templo y la segunda a la del contrato de ejecución de su policromía y dorado. Este documento se firmó el 20 de enero con el pintor Juan Calviño, vecino de Santiago de Compostela. Tendría que pintarlo junto con su imaginería y terminarlo antes de Navidad. El artista cumplió con lo acordado y el 13 de diciembre se dispuso allí el Santísimo ${ }^{78}$. Aparte del retablo mayor, la iglesia contaba en sus primeros tiempos con otros cinco altares de suma importancia. Uno de ellos el colateral de san Antonio de Padua, cuya imagen presentaba al Niño Jesús en brazos. Existía otro dedicado al Niño, cuya escultura provenía de Nápoles. Y también había retablos en honor a san Pedro de Alcántara, Nuestra Señora de la Portería o la Virgen de las Angustias, dispuesto este último en el lado del Evangelio del crucero. Todo este mobiliario se repartió por distintas iglesias de la diócesis tras la exclaustración ${ }^{79}$.

El único retablo que actualmente ocupa el lugar para el que fue destinado es el mayor de la capilla de la V.O.T. Ello se explica porque la comunidad seglar sigue vigente (fig. 8). El mueble se halla dedicado desde sus primeros tiempos a dos advocaciones marianas. Por un lado a una tan característica de los terciarios como lo es la de Nuestra Señora de la Soledad. Y por otro a una de génesis alcantarina como lo es Nuestra Señora de la Portería ${ }^{80}$. Resulta muy llamativo que la iglesia conventual y la capilla seglar tuviesen sendos altares dedicados a un culto abulense tan reciente como este. Su origen se remonta al 3 de mayo de 1718, fecha en la que a fray Luis de San José, hortelano del convento de San Antonio, se le apareció la Inmaculada en medio de una fuerte tempestad para salvarlo de una muerte segura. La Virgen le pidió que le pintase tal y como se le había manifestado, y el fraile acudió al pintor Salvador Galván. El cuadro se terminó en 1719 y se dispuso en la portería del convento. A partir de ahí arraigó con gran fuerza la devoción en Ávila

\footnotetext{
77 Francisco Javier Novo Sánchez vincula su diseño a un arquitecto conocedor de la arquitectura y retablística del entorno de León y Astorga, Novo SÁNCHez, "Retablos...”, pág. 286.

${ }^{78}$ Calviño fue contratado por 11400 reales y cobró finalmente 12222, de los cuales 10480 procedieron de donaciones de particulares, AHPLu, PNM, Lorenzo Prieto y Solloso, leg. 6262-5, fols. 3r. ${ }^{\circ}-3 v{ }^{\circ}$. Respecto a la previa ejecución del retablo, existe la certeza de que al menos se costeó con 5124 reales provenientes de limosnas, aunque sin lugar a dudas su precio total hubo ser mucho mayor, LENCE-SANTAR, Mondoñedo: El Convento de Alcántara, págs. 52, 56-57, 61, 68.

${ }^{79}$ Existían otros dos altares dedicados a San José y a un Crucificado. También un retablillo sito en el coro con las imágenes de la Virgen del Carmen, san Francisco y san Cayetano, Lence-Santar, Mondoñedo: El Convento de Alcántara, págs. 25-26, 34-36, 38, 51, 58-59, 61, 66; LóPEz, “Convento...”, págs. 86-87. Además, en su testamento de 1740, Juan Villaamil Saavedra destinó al convento la imajen de talla de $n{ }^{a}$ $s^{a}$ de la conzepcion con su escaparate en que se alla, AHPLu, PNM, Francisco Antonio Fernández de Parga, leg. 6364-1, fol. 2r. ${ }^{\text {; }}$ Lence-SAnTAR, Mondoñedo: El Convento de Alcántara, págs. 33, 63.

${ }^{80}$ Así lo indica el rótulo de su cuadro: VERDADERO RETRATO DE N. ${ }^{A} S .{ }^{A}$ DE LA PORTERIA DE ABILA Q SE VENERA EN EL COMBENTO DE S.A ANTONIO DE LA CIVDAD. BOI A SER TITVLAR DE LA CAPILLA DE MIS DEVOTOS LOS HERMANOS DE LA TERCERA ORDEN.
} 


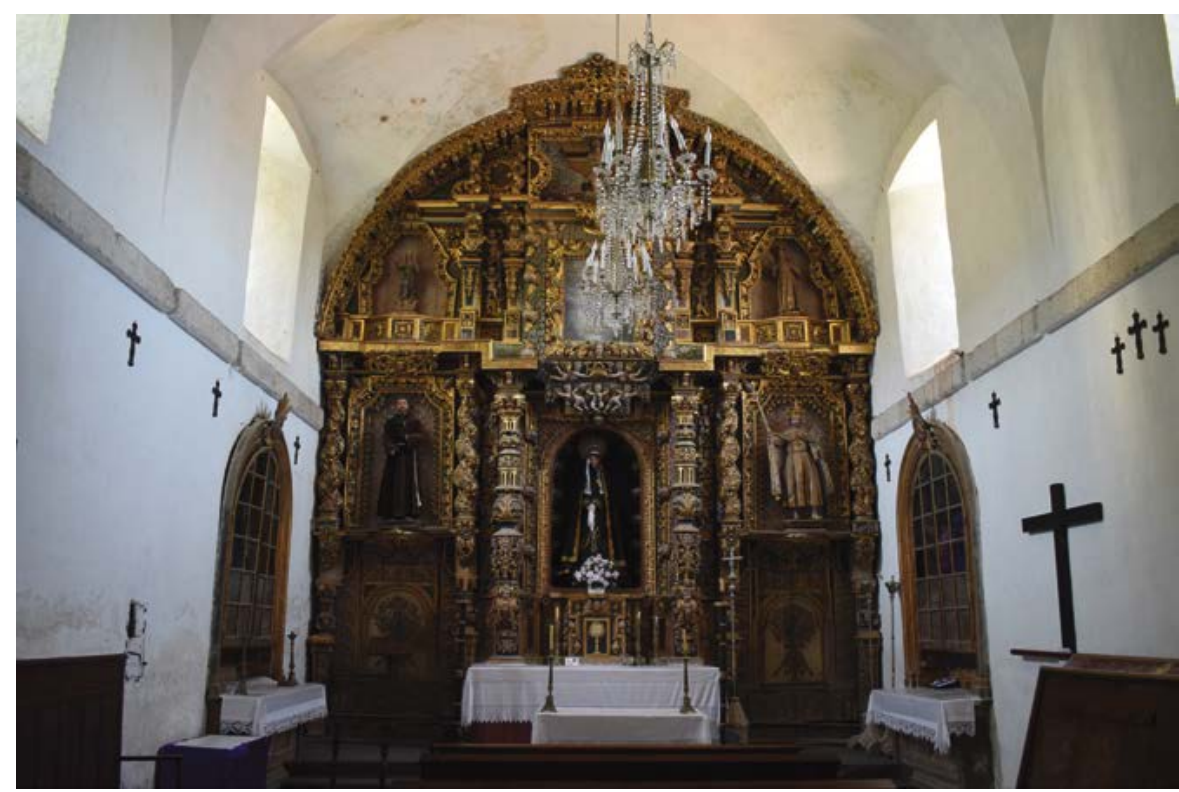

Fig. 8. Presbiterio y retablo mayor de la capilla de la V.O.T. (Fotografía del autor).

y se difundió por muchas otras zonas al tiempo que se multiplicaban las reproducciones de la imagen ${ }^{81}$. Finalmente, entre 1727-1731, justo cuando se levantaba el cenobio del Rosal, su homólogo abulense contrataba al arquitecto madrileño Pedro de Ribera para que erigiese una gran capilla dedicada a esta Virgen ${ }^{82}$.

Que surgiese este culto en Mondoñedo se explica porque uno de los primeros alcantarinos en llegar a la ciudad en 1727, el citado fray Geroteo de San Pascual, había sido guardián del convento de Ávila como mínimo entre 1718-1722, es decir, en el tiempo en que ocurrió el milagro y se propagó la devoción ${ }^{83}$. Este

\footnotetext{
${ }^{81}$ Sonsoles López González, Cayetano Sánchez Fuertes, El convento de San Antonio de Ávila y su capilla de Ntra. Sra. de la Portería, Ávila, Franciscanos Convento Santo Antonio, 1997, págs. 36-40, 50-57; Luis Quintana Giménez, Nuestra Señora de la Portería. Historia de la imagen, y de su fiel camarlengo Fr. Luis de San José, Sevilla, Punto Rojo, 2015, págs. 16-19.

82 Alfonso RodríGuez y GutiérReZ de Ceballos, Arquitectura Barroca en Castilla-León. Siglos XVII y XVIII, Salamanca, Colegio de España, 1996, págs. 78-80; LóPez GonzáLez y Sánchez Fuertes, El convento..., págs. 40-44; Matilde Verdú RuIz, El arquitecto Pedro de Ribera (1681-1742), Madrid, Instituto de Estudios Madrileños, 1998, págs. 154-161; Raimundo Moreno BlanCo, "Historia, evolución constructiva y decoración del convento de San Antonio de Ávila”, en Paula Fuentes González, Javier Gil Crespo y Santiago Huerta Fernández (eds.), Actas del Décimo Congreso Nacional y Segundo Congreso Internacional Hispanoamericano de Historia de la Construcción. Donostia-San Sebastián, 3-7 de octubre 2017, vol. 2, Madrid, Instituto Juan de Herrera, 2017, pág. 1090.

${ }^{83}$ López González y Sánchez Fuertes, El convento..., pág. 40; Quintana GimÉnez, Nuestra Señora..., pág. 105.
} 
personaje terminó siendo definidor de la provincia de San Pablo a la que estaba sujeta el cenobio mindoniense, cuya primera comunidad de frailes debió de venir enteramente de Castilla, pues aparte de no existir en Galicia ninguna familia alcantarina, el referido fray Geroteo había llegado a Mondoñedo en 1727 procedente de Baltanás (Palencia), y junto a él fray Lorenzo de Santa Teresa había hecho lo propio desde Villamañán (León) ${ }^{84}$.

Volviendo al retablo que sirve de soporte a la imagen de Nuestra Señora de la Portería, hay que recalcar que fue costeado por el mencionado Ciprián A. Gutiérrez, quien ya había financiado las obras de la capilla ${ }^{85}$. El mueble hubo de tallarse y ensamblarse antes de 1743, pues en octubre de ese año se aprobó concederle al pintor compostelano Andrés Barreira 120 reales de gratificación por haberlo pintado y dorado ${ }^{86}$. Con lo cual, el desconocido taller que lo ejecutó tuvo que efectuarlo entre 1735 y $1743^{87}$. De hecho no fue hasta noviembre de 1735 cuando la congregación le pidió a Ciprián que buscase a un artista para llevar a cabo las imágenes de la Virgen de la Soledad y del Ecce Homo con vistas a procesionarlas el Domingo de $\operatorname{Ramos}^{88}$. Eran estas dos devociones muy vinculadas a los terciarios seglares, al igual que el resto del santoral de las hornacinas

\footnotetext{
${ }^{84}$ Lence-Santar, Mondoñedo: El Convento de Alcántara, pág. 15; y Mondoñedo. El Convento de San Martín..., págs. 89, 91 .

${ }^{85}$ Esto lo sabemos por una escritura que data del 10 de mayo de 1749. El documento trata de una fundación de misas y dotación de aceite en dicho recinto. Ciprián había mejorado el ajuar de la capilla recientemente con una lámpara de plata de 74 onzas y un copón argénteo de 11. Entonces tan solo faltaba colocar el Santísimo, de ahí la asignación del aceite y la entrega de la lámpara, AHPLu, PNM, Francisco Antonio Fernández de Parga, leg. 7333-6, fols. 44r. ${ }^{\circ}-44 v .^{\circ}$; Lence-SAntar, Mondoñedo: La Orden Tercera, pág. 5. El Sacramentado se dispuso finalmente el 10 de agosto de 1749. Dos años después falleció el promotor de la capilla, quien tenía derecho a dos sepulturas frente al mencionado altar de la Virgen de la Soledad, Lence-Santar, Mondoñedo: La Orden Tercera, págs. 5-6. Sobre este personaje v. José Isidro FernáNDez Villalba, Mondoñedo, regreso al pasado III. Recopilación de artículos publicados en diversos medios de comunicación por Don Eduardo Lence-Santar y Guitián, Mondoñedo, Museo Catedralicio y Diocesano de Mondoñedo, 2001, págs. 47-50.

${ }^{86}$ Lence-Santar, Mondoñedo: La Orden Tercera, pág. 4. Hubo quien creyó que el mencionado Barreira era un escultor, razón por la cual le asignó la autoría de este mueble, y, por similitudes formales, el retablo mayor de la iglesia parroquial de San Xoán de Sistallo (Cospeito, Lugo), José Manuel García IGLESIAS, El Barroco (II). Arquitectos del siglo XVIII. Otras actividades artísticas, A Coruña, Hércules, 1993 (Galicia Arte, 14), págs. 403-404.

${ }^{87}$ Iván Rega Castro ha defendido que el entallador del retablo hubo de ser el mismo que el que hizo $a$ posteriori el de la capilla mayor de la iglesia de agustinas recoletas de Betanzos. También ha advertido en ambos un influjo de la retablística asturiana, Iván REGA CASTRO, "Apuntes para el estudio del convento de las Agustinas Recoletas de Betanzos: forma y contenido en el retablo mayor de la Anunciación", Anuario Brigantino, núm. 29 (2006), págs. 369-386. Antes que él ya había señalado ciertas semejanzas entre ambos Leopoldo Fernández Gasalla, "Estudio histórico-artístico del hospital y convento de la Anunciación de Betanzos (1505-1874)", en María del Carmen Folgar de la Calle, Ana Goy Diz, José Manuel López Vázquez (coords.), Memoria artis. Studia in memoriam Ma Dolores Vila Jato, Santiago de Compostela, Xunta de Galicia, 2003, pág. 283. Sin embargo Francisco Javier Novo Sánchez ha atribuido su diseño a fray Lorenzo de Santa Teresa, Novo SÁnchez, "Retablos...”, pág. 286.

${ }^{88}$ Lence-Santar, Mondoñedo: La Orden Tercera, pág. 3.
} 
laterales, contándose a san Francisco, san Luis rey de Francia, santa Isabel de Hungría y santa Rosa de Viterbo.

\section{CONCLUSIÓN}

El convento de San Francisco del Rosal fue el último en erigirse en el Mondoñedo moderno. El obispo Muñoz y Salcedo resultó el principal culpable de su fundación y construcción. En años anteriores ya había demostrado su preocupación por el clero regular de la ciudad financiando la renovación del cenobio de la Encarnación y de la iglesia de San Martiño de Vilalourente. El monasterio alcantarino, al igual que sus precedentes, se caracterizó por la austeridad formal en su arquitectura, siendo aquí más acusada si cabe. Esto se explica por dos razones fundamentales: por la falta de patrocinadores lo suficientemente pudientes como para levantar un convento más fastuoso; y porque la idiosincrasia de esta rama franciscana casaba a la perfección con la promulgación de valores como la humildad y la pobreza. Precisamente ahí radica su particularidad más diferencial, pues su arquitectura pétrea careció de adorno alguno en un momento en el que triunfaba un barroco más exuberante y dinámico en el Reino de Galicia, un territorio periférico que, por cierto, no conoció otra casa alcantarina que no fuese la de Mondoñedo.

\section{BIBLIOGRAFÍA}

Araya Iglesias, Carmen; Grau Lobato, Germán, "Monumentos histórico-artísticos alcantarinos en la provincia de Badajoz", San Pedro de Alcántara, hombre universal. Congreso de Guadalupe, 1997, Guadalupe, Ediciones Guadalupe, 1998, págs. 509-588.

Araya Iglesias, Carmen; Grau Lobato, Germán, "Lugares alcantarinos en la provincia de Badajoz”, Revista de Estudios Extremeños, 57, núm. 1 (2001), págs. 49-72.

Cal Pardo, Enrique, "Episcopologio Mindoniense. Primera mitad del siglo XVIII", Estudios Mindonienses, núm. 17 (2001), págs. 277-422.

Cal Pardo, Enrique, Episcopologio Mindoniense, Santiago de Compostela, CSIC-Xunta de Galicia, Instituto de Estudios Gallegos "Padre Sarmiento"; Mondoñedo-Ferrol, Estudios Mindonienses, 2003 (Anejos de Cuadernos de Estudios Gallegos, 28).

Couselo Bouzas, José, Galicia artística en el siglo XVIII y primer tercio del XIX, Compostela, Seminario, 1932.

Domínguez de Valdeón, Teodoro, El libro de Villamañán. Guía eclesiástica, geográfica, histórica, biográfica, bibliográfica, y turística de esta ilustre villa, León, Diputación Provincial, 1928.

Fernández Fernández, José M., “Oposición de los franciscanos de Villaoriente a la construcción del Convento de Alcantarinos, en Mondoñedo", Estudios Mindonienses, núm. 13 (1997), págs. 739-751.

Fernández Gasalla, Leopoldo, "Estudio histórico-artístico del hospital y convento de la Anunciación de Betanzos (1505-1874)”, en María del Carmen Folgar de la Calle, Ana Goy Diz, 
José Manuel López Vázquez (coords.), Memoria artis. Studia in memoriam Ma Dolores Vila Jato, Santiago de Compostela, Xunta de Galicia, 2003, págs. 269-287.

Fernández González, Alberto, "Fuentes gráficas para el estudio de tres edificios históricos de Sevilla: las plantas de los conventos de la Santísima Trinidad, San Francisco de Paula y San Pedro de Alcántara", De Arte, núm. 11 (2012), págs. 155-166.

Fernández Villalba, José Isidro, Mondoñedo, regreso al pasado III. Recopilación de artículos publicados en diversos medios de comunicación por Don Eduardo Lence-Santar y Guitián, Mondoñedo, Museo Catedralicio y Diocesano de Mondoñedo, 2001.

Fernández Villalba, José Isidro, Mondoñedo, regreso al pasado VII. Recopilación de artículos publicados en diversos medios de comunicación por Don Eduardo Lence-Santar y Guitián, Mondoñedo, Suc. de Mancebo, 2010.

Fernández Villalba, José Isidro; San Cristóbal Sebastián, Santos, El convento de San Pedro de Alcántara, Mondoñedo, Mancebo, 2006.

Flórez, Henrique, España Sagrada. Theatro Geographico Historico de la Iglesia de España. Origen, divisiones, y limites de todas sus Provincias. Antiguedad, Traslaciones, y estado antiguo y presente de sus Sillas, con varias Disertaciones criticas. Tomo XVIII. De las Iglesias Britoniense, y Dumiense, incluidas en la actual de Mondoñedo, Madrid, Antonio Marín, 1764.

Freyre, Xe, Mondoñedo, León, Everest, 1990.

Gallego Jorreto, Manuel, “Actuaciones en Mondoñedo. Lugo. España”, Tribuna de la Construcción, núm. 118 (2015), págs. 132-153.

García Doural, Andrés, "La nueva residencia de los P.P. de Alcántara”, Miscelánea Mindoniense [blog] 29 (julio.2012), disponible en <www.blogoteca.com/doural/> [Consulta: $14 / 01 / 2018]$.

García Doural, Andrés, "La capilla de la Concepción de Mondoñedo", Miscelánea Mindoniense [blog] 20 (enero.2018), disponible en <www.blogoteca.com/doural/> [Consulta: 28/06/2019].

García Iglesias, José Manuel, El Barroco (II). Arquitectos del siglo XVIII. Otras actividades artísticas, A Coruna, Hércules, 1993 (Galicia Arte, 14).

García Iglesias, José Manuel (dir.); Garrido Moreno, Antonio (aut.), Arquitecturas no Camiño, 1994-2004. Colexio Oficial de Arquitectos de Galicia (COAG). Santiago de Compostela 30 xullo / 31 outubro 2004, Santiago de Compostela, Xunta de Galicia, 2004.

Gómez Darriba, Javier, “«Reconstruyendo» una ruina del siglo XVII. El desaparecido convento de la Encarnación de Mondoñedo”, Sémata, núm. 31 (2019), págs. 251-272.

González Reboredo, José Manuel; San Cristóbal Sebastián, Santos; Rielo Carballo, Nicanor; Valiña Sampedro, Elías, Inventario artístico de Lugo y su provincia, t. 3, Madrid, Ministerio de Cultura, 1980.

Graña Cid, María del Mar, Las órdenes mendicantes en el obispado de Mondoñedo. El convento de San Martín de Villaoriente (1374-1500), Salamanca, Estudios Mindonienses, 1990.

Hipólito Ojalvo, Francisco A., "El patrimonio arquitectónico alcantarino de la provincia de Cáceres", San Pedro de Alcántara, hombre universal. Congreso de Guadalupe, 1997, Guadalupe, Ediciones Guadalupe, 1998, págs. 479-508. 
Lence-Santar y Guitián, Eduardo, Mondoñedo: El Santuario de los Remedios, Mondoñedo, César G. Seco Romero, 1909.

Lence-Santar y Guitián, Eduardo, Mondoñedo: La Orden Tercera, Mondoñedo, César G. Seco Romero, 1910.

Lence-Santar y Guitián, Eduardo, Mondoñedo: El Convento de Alcántara, Mondoñedo, César G. Seco Romero, 1910.

Lence-Santar y Guitián, Eduardo, Mondoñedo: El Convento de la Concepción, Mondoñedo, César G. Seco, 1910.

Lence-Santar y Guitián, Eduardo, Mondoñedo. El Convento de San Martín de Villaoriente o de los Picos, Lugo, Sucr. de A. Villamarín, 1912.

Lence-Santar y Guitián, Eduardo, Del Obispado de Mondoñedo, Mondoñedo, 1915, t. 3.

López, Atanasio, "Convento de San Pedro de Alcántara de Mondoñedo. (Fragmentos de una Chrónica ms.)", Archivo Ibero-Americano, núm. 28 (1918), págs. 71-93.

López González, Sonsoles; Sánchez Fuertes, Cayetano, El convento de San Antonio de Ávila y su capilla de Ntra. Sra. de la Portería, Ávila, Franciscanos Convento Santo Antonio, 1997.

Martín García, Alfredo, "Predicación franciscana y asociacionismo seglar: las Terceras Órdenes gallegas en la Edad Moderna", en José Miguel Andrade Cernadas, Raquel Casal García y Roberto J. López López (eds.), Galicia monástica. Estudos en lembranza da profesora María José Portela Silva, Santiago de Compostela, Universidade de Santiago de Compostela, 2009, págs. 361-380.

Morais Vallejo, Emilio, Aportación al barroco en la provincia de León. Arquitectura religiosa, León, Universidad de León, 2000.

Moreno Blanco, Raimundo, "Historia, evolución constructiva y decoración del convento de San Antonio de Ávila”, en Paula Fuentes González, Javier Gil Crespo y Santiago Huerta Fernández (eds.), Actas del Décimo Congreso Nacional y Segundo Congreso Internacional Hispanoamericano de Historia de la Construcción. Donostia-San Sebastián, 3-7 de octubre 2017, vol. 2, Madrid, Instituto Juan de Herrera, 2017, págs. 1085-1094.

Novo Sánchez, Francisco Javier, "Retablos barrocos de la ciudad de Mondoñedo", en Francisco Singul Lorenzo (dir.), Rudesindus. La tierra y el templo. Catedral de Mondoñedo. 8 de mayo - 29 de junio, 2007, Santiago de Compostela, Xunta de Galicia, págs. 281-293.

Pita Galán, Paula, Los frailes arquitectos del siglo XVIII en Galicia: trayectoria artística de los maestros regulares de las órdenes de San Benito, San Francisco y Santo Domingo, Tesis Doctoral, Santiago de Compostela, Universidade de Santiago de Compostela, 2019.

Quintana Giménez, Luis, Nuestra Señora de la Portería. Historia de la imagen, y de su fiel camarlengo Fr. Luis de San José, Sevilla, Punto Rojo, 2015.

Rega Castro, Iván, "Apuntes para el estudio del convento de las Agustinas Recoletas de Betanzos: forma y contenido en el retablo mayor de la Anunciación", Anuario Brigantino, núm. 29 (2006), págs. 369-386.

Río Ramos, Laura, "San Pedro de Alcántara", en Francisco Rodríguez Iglesias (dir.), Mosteiros e conventos da Península Ibérica. Galicia, vol. 6, A Coruña, Hércules, 2008, págs. 68-79.

Rodríguez y Gutiérrez de Ceballos, Alfonso, Arquitectura Barroca en Castilla - León. Siglos XVII y XVIII, Salamanca, Colegio de España, 1996. 
Saavedra Fernández, Pegerto, Economía, Política y Sociedad en Galicia: la provincia de Mondoñedo, 1480-1830, Madrid, Xunta de Galicia, 1985.

San Cristóbal Sebastián, Santos, La ciudad de Mondoñedo, Lugo, Caja de Ahorros de La Coruña y Lugo, 1975.

San Cristóbal Sebastián, Santos, "Convento de San Pedro de Alcántara”, Cuadernos del Museo Mindoniense, núm. 12 (1986), págs. 11-32.

San Cristóbal Sebastián, Santos, Monasterio de la Concepción de Mondoñedo, Lugo, Diputación Provincial de Lugo, 2001.

Verdú Ruiz, Matilde, El arquitecto Pedro de Ribera (1681-1742), Madrid, Instituto de Estudios Madrileños, 1998.

Vigo Trasancos, Alfredo, "La ciudad de Mondoñedo en el siglo XVIII. La renovación urbana de una antigua sede episcopal”, Estudios Mindonienses, núm. 15 (1999), págs. 519-553. 